\title{
THE LEGITIMACY OF COMPARATIVE CONSTITUTIONAL LAW: A MODAL EVALUATION
}

\author{
Bradley Silverman ${ }^{*}$
}

INTRODUCTION

I. THE PARTICIPATORY CONSTITUTION AND BOBBITT'S MODAL

TAXONOMY

II. The LeGitimacy OF Citing Foreign LAW AS A MODAL

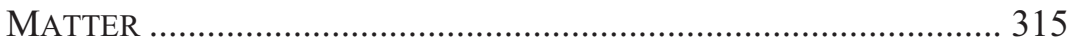

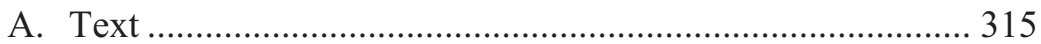

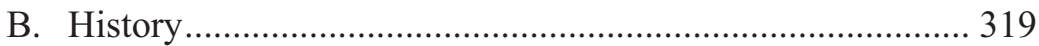

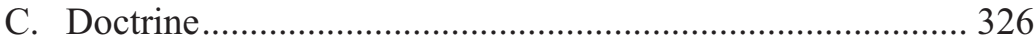

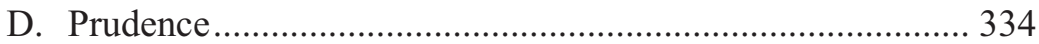

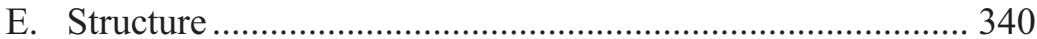

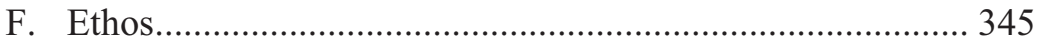

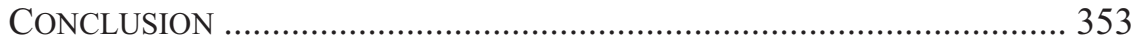

\section{INTRODUCTION}

In recent years, there has been intense debate - within the judiciary, ${ }^{1}$ academia, ${ }^{2}$ the press $^{3}{ }^{\text {even Congress }}{ }^{4}$ - over the legitimacy of using

* J.D. Candidate, Yale Law School, 2016. I am grateful to Steven G. Calabresi, Akhil Reed Amar, and Philip C. Bobbitt for inspiration, as well as to Jack Sklarski and the editors of the Michigan State International Law Review for all of their support and assistance over the course of the production process.

1. See, e.g., Roper v. Simmons, 543 U.S. 551, 575 (2005) ("[T]he stark reality [is] that the United States is the only country in the world that continues to give official sanction to the juvenile death penalty."); Roper, 543 U.S. at 624 (Scalia, J., dissenting) ("[T]he basic premise of the Court's argument - that American law should conform to the laws of the rest of the world - ought to be rejected out of hand. . . ."); Lawrence v. Texas, 539 U.S. 558, 577 (2003) ("The right the petitioners seek in this case has been accepted as an integral part of human freedom in many other countries. There has been no showing that in this country the governmental interest in circumscribing personal choice is somehow more legitimate or urgent."); Lawrence, 539 U.S. at 598 (Scalia, J., dissenting) ("Constitutional entitlements do not spring into existence because some States choose to lessen or eliminate criminal sanctions on certain behavior. Much less do they spring into existence, as the Court seems to believe, because foreign nations decriminalize conduct.") (emphasis in original); Foster v. Florida, 537 U.S. 990, 990 n.* (2002) (Thomas, J., concurring) ("[T]his Court's . . jurisprudence should not impose foreign moods, fads, or fashions on Americans."); Foster, 537 U.S. at 992 (Breyer, J., 
dissenting) ("Courts of other nations have found that delays of 15 years or less can render capital punishment degrading, shocking, or cruel."); Atkins v. Virginia, 536 U.S. 304, 316 n.21 (2002) ("Moreover, within the world community, the imposition of the death penalty for crimes committed by mentally retarded offenders is overwhelmingly disapproved."); Atkins, 536 U.S. at 322 (Rehnquist, C.J., dissenting) (criticizing "the Court's decision to place weight on foreign laws").

2. See, e.g., Robert J. Delahunty \& John Yoo, Against Foreign Law, 29 HARV. J.L. \& PUB. POL'Y 291, 296 (2005) ("Foreign and international law cannot be legitimately used in an outcome-determinative way to decide questions of constitutional interpretation."); Frank H. Easterbrook, Foreign Sources and the American Constitution, 30 Harv. J.L. \& Pub. Pol'y 223, 229 (2006) ("There is no . . power in the judiciary to make any norm of international law binding within the United States."); Ruth Bader Ginsburg, Looking Beyond Our Borders: The Value of a Comparative Perspective in Constitutional Adjudication, 22 YALE L. \& Pol'y ReV. 329, 329 (2003) ("We are the losers if we do not both share our experience with, and learn from others."); David C. Gray, Why Justice Scalia Should Be a Constitutional Comparativist . . . Sometimes, 59 STAN. L. REV. 1249, 1276 (2007) ("[T] he fundamental tenets of originalism commit its adherents to refer to foreign law when engaging a narrow band of constitutional questions."); Eric A. Posner \& Cass R. Sunstein, The Law of Other States, 59 STAN. L. REV. 131, 136 (2006) ("Our goal here is to set out a framework for assessing the question of whether courts should consult the practices of other states, either domestically or nationally."); Nicholas Quinn Rosenkranz, Condorcet and the Constitution: A Response to The Law of Other States, 59 StAn. L. Rev. 1281, 1283 (2007) ("[T]he Constitution itself ultimately refutes the notion that it should be interpreted by reference to the law of other states."); Ernesto J. Sanchez, A Case Against Judicial Internationalism, 38 ConN. L. REv. 185, 191 (2005) ("[C]ourts should never use ... [foreign law] to any degree in instances where the specific disputes they consider . . . do not actually necessitate such a reference under the Constitution.").

3. See, e.g., Editorial: Kagan's Foreign Law Trumps Con-Law, Wash. Times (May 25, 2010), www.washingtontimes.com/news/2010/may/25/kagan-foreign-lawtrumps-con-law/ ("Solicitor General Elena Kagan's nomination to the Supreme Court should founder unless she adequately explains why she quite literally put 'International/Comparative Law' ahead of the U.S. Constitution.'); Daniel Terris, Sotomayor's Cautious Openness to Foreign Laws, Boston Globe (July 16, 2009), www.boston.com/bostonglobe/editorial_opinion/oped/articles/2009/07/16/sotomayors_ca utious_openness_to_foreign_laws/ ("[A] burgeoning respect for judges and courts from overseas should help further the heartening idea that the United States is not a nation unto itself, but a nation among nations, working toward justice for its own citizenry and for men and women around the globe."); Collin Levy, Sotomayor and International Law, Wall St. J. (July 14, 2009, 12:01 AM) www.wsj.com/articles/SB124753085258335815 ("[U]sing foreign law as a guidepost or inspiration raises issues of both sovereignty and democracy by permitting jurists outside the U.S. system to guide the trajectory of our democracy."); Sean D. Murphy, The Law of the Lands: Why US Courts Look Overseas, Boston Globe (June 5, 2005), 
foreign law in American courts. This question cannot be answered, however, unless one knows what the relevant criteria for constitutional legitimacy are. By what standards should we decide whether it is appropriate for American courts to cite foreign law in their decisions? Before we can figure out whether it is constitutionally proper for American courts to use foreign law, we need to first agree on what makes something constitutionally proper.

In a pair of path-breaking books, Constitutional Fate: Theory of the Constitution $^{5}$ and Constitutional Interpretation, ${ }^{6}$ Philip C. Bobbitt offers a modal approach to constitutional argument, presenting six different types, or modalities, through which constitutional discourse is channeled. They are appeals from text, history, doctrine, prudence, structure, and ethos. ${ }^{7}$ According to Bobbitt, this taxonomy of argumentative forms resolves the counter-majoritarian dilemma by showing that there was no dilemma in the first place. ${ }^{8}$ Judicial review is legitimated, he says, by our

www.boston.com/news/globe/editorial_opinion/oped/articles/2005/

06/05/the law of the lands/ ("Today, the continued development of US constitutional law can benefit from the experiences of other countries. Without abdicating sovereignty, we can learn from other countries' successes and failures.").

4. For instance, Congressman Ted Poe has observed that Americans "spilled their blood . . . to sever ties with England forever," but says that "[n]ow, justices in this land of America ... use British court decisions ... in interpreting our Constitution. What the British could not accomplish by force, our Supreme Court has surrendered to them voluntarily." 151 Cong. Rec. H3105 (daily ed. May 10, 2005) (statement of Rep. Poe). Meanwhile, Senator John Cornyn has warned that "the American people may be slowly losing control over the meaning of our laws and of our Constitution," and that "foreign governments may even begin to dictate what our laws and our Constitution mean, and what our policies in America should be." 151 Cong. Rec. S3109 (daily ed. Mar. 20, 2005) (statement of Sen. Cornyn). In 2004, the House of Representatives considered a resolution expressing its "sense ... that judicial determinations regarding the meaning of the laws of the United States should not be based in whole or in part on judgments, laws, or pronouncements of foreign institutions unless" they "are incorporated into the legislative history of laws passed by the elected legislative branches of the United States or otherwise inform an understanding of the original meaning of the laws of the United States." H.R. Res. 568, 108th Cong. (2004). (1982).

5. Philip C. Bobbitt, Constitutional Fate: Theory of the Constitution

6. Philip C. BobBitT, CONSTitutional InTERPRETATION (1991).

7. Id. at $12-13$.

8. Id. at 8 ("[J]udicial review is one of those by no means rare issues in constitutional law that presents an easy case. . . . It was the attempt to meet this [Countermajoritarian] Objection that generated my description and discussion of six 
adherence to these forms of constitutional reasoning; we accept law arguments that sound in one or more of these modalities as legitimate, but we reject things that purport to be constitutional claims yet which don't take at least one of these six modal forms. ${ }^{9}$ Though the six modalities allow for distinctions to be drawn between different types of constitutional assertions, the important thing about them is not that they allow us to classify constitutional arguments, but rather that they enable us to distinguish bona fide constitutional arguments from arguments that simply are not constitutional in character.

This Article will attempt to evaluate the legitimacy of the practice of comparative constitutional law by American courts through modal lenses. It will ask one question - is it legitimate for our judges to cite foreign law? - six times, each time analyzing it within a particular modal framework; textual, historical, doctrinal, prudential, structural, and ethical. Using those methodological tools, it will then seek to provide one answer. It is important to understand what this Article will not do; it will not attempt to evaluate the usefulness of comparative constitutional law within the various modalities. Whether it makes sense to present a comparative law claim as a textual assertion, or a doctrinal assertion, or so on-whether comparative law arguments are more persuasive when they take particular modal forms - is beyond the scope of this Article. The sole question is whether, evaluated as a modal matter, it is constitutionally permissible to use foreign law.

Many of the arguments explored below will be familiar ones, raised by prominent jurists and scholars in favor or against the citation of foreign law. This Article makes no claim to the originality of most of these arguments. Rather, it attempts to categorize these arguments by the types of reasoning they use-textual, historical, doctrinal, prudential, structural, or ethical - and thus demonstrate how the citation of foreign law can be either legitimated or illegitimated within the various modal frameworks. The arguments themselves, with some original exceptions, belong to others. By presenting them in this taxonomical framework, this Article seeks to identify how a textualist, or a historicist, or a doctrinalist,

modalities of constitutional argument. ... [That] maintained the legitimacy of judicial review.").

9. See id. (The modalities "maintained the legitimacy of judicial review in the United States.”). 
or so on, would go about evaluating the question of whether the citation of foreign law by American judges is legitimate.

\section{THE PARTICIPATORY CONSTITUTION AND BOBBITT'S MODAL TAXONOMY}

In Constitutional Fate ${ }^{10}$ and Constitutional Interpretation, ${ }^{11}$ Bobbitt lays out a vision of what he calls the "participatory Constitution." 12 Bobbitt distinguishes his approach from those of the legal formalists and the legal realists, both of whom implicitly accept an assumption that "the statement of a legal rule is either true or false depending on whether it stands for a legal fact." ${ }^{13}$ Formalists, he says, simply believe that law is a thing we have and excluding "inconsistent decisions as wrongly decided," 14 while realists believe that the "mass of contradictory statements" in what judges do means that we don't really have law at all. ${ }^{15}$ Either way, both camps "treat[] legal rules as if they derived their validity from the truths they express about a world."16

Bobbitt rejects this approach. The stuff of law, he says, is not factual propositions about the state of the world that have a definite truthful character. ${ }^{17}$ Instead, he says, it "consists of resolving questions in the context of the conventions that provide the methods for answering them." ${ }^{18}$ Law, according to Bobbitt, "is something we do, not something we have as a consequence of something we do." ${ }^{19}$ It is expressed in "the formulation of rules," or modalities of interpretation, "and not propositions," or legal fact-statements. ${ }^{20}$ The modalities, Bobbitt believes, are conventions within which disputes over the compatibility of particular laws with the Constitution can be resolved, but they arise from a relationship between the Constitution itself and "the larger culture with

10. BoBBITT, supra note 5 .

11. Bоввітт, supra note 6.

12. See BoBвitT, supra note 5, at 235 .

13. Id.

14. Id.

15. Id.

16. Id.

17. Id. at 234-35.

18. Id. at 236 .

19. BoвBiтt, supra note 6, at 24 (emphasis added).

20. BoBвIT, supra note 5, at 236. 
whom the various constitutional functions serve to assure a fluid, twoway effect on the ongoing process of constitutional meaning." 21 Constitutional meaning, then, is constructively negotiated through the practice of argument and appeal made within the proper forms. ${ }^{22}$

These forms, what Bobbitt calls modalities, are textualism, historicisim, doctrinalism, prudentialism, structuralism, and ethicismappeals to the Constitution's text, history, doctrine, prudence, structure and ethos. There is no order of operations inherent in use of the modalities; there is no rule by which conflicting modal appeals are reconciled or held to trump one another. ${ }^{23}$ Rather, conflict between the modalities creates "a legitimate role for conscience" in our system of constitutional decision-making-"an opportunity for justice consistent with the freedom of the conscience to decide matters." 24 This Article's task will be to evaluate the legitimacy of the citation of foreign law through the lenses of these modalities. But first, a brief introduction to each of these modal forms.

Textual argument relies on "a consideration of the present sense of the words of the provision" in question. ${ }^{25}$ They "rest on a sort of ongoing social contract, whose terms are given their contemporary meanings continually reaffirmed by the refusal of the People to amend the instrument." ${ }^{\text {"26 }}$ Justice Joseph Story said that "there can be no security to the people in any constitution of government if they are not to judge of it by the fair meaning of the words in the text." ${ }^{27}$ One appeal of textualism is its democratic pedigree; ordinary people may know little about case law or the historical debates that occurred at the time the Constitution was created, but anyone can read the text. "Constitutions," Story said,

21. Id. at $234-35$.

22. See Ian C. Bartrum, Metaphors and Modalities: Meditations on Bobbitt's Theory of the Constitution, 17 WM. \& MARY BILL RTS. J. 157, 157 (2008) (Bobbitt asserts, "the Constitution is not an artifact that exists in some space apart from us; whose nature we might better search out by poking, teasing, or holding up to the proper light. Rather the Constitution is the search: it is neither more nor less than the practice ... of constitutional law.").

23. See generally BoBвiT, supra note 6, at 141-54.

24. Id. at 163 .

25. BoBBitT, supra note 5, at 7.

26. Id. at 26.

27. 1 Commentaries on the Constitution of the United States $\S 407$, at 390 n.10 (Joseph Story ed. 1st ed. 1833). 
"are instruments of a practical nature, founded on the common business of human life, adapted to common wants, designed for common use, and fitted for common understanding. The people make them; the people adopt them; the people must be supposed to read them." 28 Professor Akhil Amar notes that the entirety of the Constitution's text runs fewer than 8,000 words, "a half hour's read for the earnest citizen"; in this way, it actively "invites us to explore its substance." 29

Historical argument "marshals the intent of the draftsmen of the Constitution and the people who adopted the Constitution." ${ }^{30}$ They "depend on a determination of the original understanding of the constitutional provision to be construed." modality is the notion "that the Constitution bound government and that the People had therefore devised a construction by which they could enforce its limits and rules." ${ }^{32}$ Bobbitt believes that historical argument is most useful "to negative a particular interpretation but not to establish a single meaning conclusively." 33 To approach a constitutional question within the historical modality, one might ask whether "the framers and ratifiers of the Fourteenth Amendment intended, or did not intend, or that it cannot be ascertained whether it was their intention," a certain thing. ${ }^{34}$ What we today call originalism is historical argument. ${ }^{35}$

Doctrinal argument "asserts principles derived from precedent or from judicial or academic commentary on precedent." ${ }^{" 36}$ The selection of onpoint precedents, the fashioning of general principles from multiple individual cases - these are in service of a desire to achieve principled, consistent, predictable decision-making. Doctrinal argument is often "almost wholly based on precedent and is derived from the doctrines that have accreted around various constitutional provisions." 37 Doctrinal appeals are rooted in the notion of "rule of law," and contain "at least

28. Id. $\S 451$, at 436-37.

29. AKHil ReEd Amar, AmericA's CONSTItUtion: A Biography xi (2005).

30. BoBBitT, supra note 5, at 7.

31. Id. at 9 .

32. Id. at 10.

33. Id. at 21.

34. BoBBIT, supra note 6, at 13.

35. See generally Originalism: A Quarter-Century of Debate (Steven G. Calabresi ed.) (2007).

36. BoBBITT, supra note 5, at 7.

37. Id. at 41 . 
two clear distinction. First, legislative policy making must be distinguished from judicial rule applying." ${ }^{38}$ Second, and perhaps even more importantly, "judicial rule applying must be a reasoned process of deriving the appropriate rules and following them in deciding any practical controversy between adverse parties without regard to any fact not relevant to the rules." ${ }^{39}$

Prudential argument, meanwhile, is "constitutional argument which is actuated by the political and economic circumstances surrounding the decision." ${ }^{40}$ It "is self-conscious to the reviewing institution and need not treat the merits of the particular controversy . . . instead advancing particular doctrines according to the practical wisdom of using the courts in a particular way." ${ }^{\text {41 }}$ Sometimes, this means refraining from deciding a matter altogether; this is what Bobbitt means when he says that "a court's first responsibility is to decide whether it should decide." 42 To avoid adjudicating cases and controversies on the merits, prudentialist judges may employ the tools of "discretionary standing, the grant of certiorari and the dismissal of appeal, the doctrines of vagueness, ripeness, and political question, and others." ${ }^{43}$

Structural arguments involve "inferences from the existence of constitutional structures and the relationships which the Constitution ordains among these structures." ${ }^{44}$ They assert "that a particular principle or practical result is implicit in the structures of government and the relationships that are created by the Constitution among citizens and governments." ${ }^{45}$ Unlike prudential arguments, structure appeals "are largely factless and depend on deceptively simple logical moves from the entire Constitutional text rather than from one of its parts." ${ }^{46}$ Bobbitt describes structural appeals as "embody[ing] a macroscopic prudentialism drawing not on the peculiar facts of the case but rather arising from general assertions about power and social choice." ${ }^{, 47}$

$\begin{array}{ll}\text { 38. } & I d . \\ 39 . & I d . \\ 40 . & I d . \text { at } 61 . \\ 41 . & I d . \text { at } 7 . \\ 42 . & I d . \text { at } 63 . \\ 43 . & I d . \text { at } 66 . \\ 44 . & I d . \text { at } 74 . \\ 45 . & I d . \text { at } 7 . \\ 46 . & I d . \text { at } 74 . \\ 47 . & I d .\end{array}$


Structuralism is associated with the person credited as having first articulated it, Professor Charles L. Black, Jr. ${ }^{48}$

Finally, ethical argument "denotes an appeal to those elements of the American cultural ethos that are reflected in the Constitution." identifies " $t$ the fundamental American constitutional ethos" as "the idea of limited government, the presumption of which holds that all residual authority remains in the private sphere." ${ }^{50}$ Unlike Lochnerism, which limits the ends that governments may pursue, arguments from ethos are directed at the impermissible means by which governments may pursue ends that are indisputably legitimate. ${ }^{51}$ Appeals to ethos "do not depend on the construction of any particular piece of text, but rather on the necessary relationships that can be inferred from the overall arrangement expressed in the text." ${ }^{52}$ Ethical arguments are rooted in "the fundamental constitutional arrangement by which rights, in the American system, can be defined as those choices beyond the power of government to compel., ${ }^{, 3}$

\section{The Legitimacy of Citing Foreign LAW AS A Modal Matter}

Now that the Bobbitt modalities have been introduced, it is time to evaluate whether the citation of foreign law is internally legitimate within each of them.

\section{A. Text}

Is it ever constitutionally legitimate to use foreign sources of law to interpret the U.S. Constitution? To answer this question, a textualist would begin, unsurprisingly, by looking to the Constitution's text. On its face the Constitution doesn't seem to authorize the citation of foreign law. No provision in it expressly allows its interpreters to rely on foreign law. This stands in contrast to South Africa's 1996 constitution, which

48. See Charles L. Black, JR., Structure AND Relationship IN Constitutional LaW (1969).

49. BовBITT, supra note 6 , at 20.

50. Id.

51. See BobBitT, supra note 5, at 147-54.

52. BoBBiTT, supra note 6, at 20.

53. Id. 
expressly says that courts, tribunals and forums "may consider foreign law" 54 when interpreting the Bill of Rights. To a certain type of textualist, the absence of any similar provision in the U.S. Constitution would be dispositive - citing foreign law is impermissible.

A textualist may be tempted to conclude that the Constitution bars using foreign law in interpreting itself based on an inference drawn from Article VI, which says that "[t]his Constitution, and the Laws of the United States which shall be made in Pursuance thereof; and all Treaties made, or which shall be made, under the Authority of the United States, shall be the supreme Law of the Land." ${ }^{55}$ The inference would be that because Article VI provides an exhaustive enumeration of what counts as the "supreme Law of the Land" 56 - namely, the Constitution, federal laws, and treaties - anything that isn't the Constitution, a federal law, or a treaty therefore can't be the supreme law of the land.

But this argument would misunderstand the question. Almost nobody believes that foreign law ought to be considered the law of the land qua foreign law, any more than we believe that law review articles ought to be considered the law of the land qua law review articles, or that treatises ought to be considered the law of the land qua treatises; these are all materials that can help us understand what, precisely, the Constitution means when it says something, not materials that are themselves the Constitution. $^{57}$ In other words, citing Article VI only pushes the underlying issue up one level into a different realm of abstraction; instead of asking whether foreign law is of a hierarchically equal statute to American law (which, again, is a straw man question), we are asking whether foreign law can help us understand what American law means.

So the Constitution's text doesn't overtly speak to the propriety of citing foreign law one way or the other. Does that mean that relying on foreign law is illegitimate as a matter of textualism? Perhaps not; there

54. S. Afr. CONST., 1996, § 39(1)(c).

55. U.S. CONST. art. VI, cl. 2.

56. Id.

57. See Norman Dorsen, The Relevance of Foreign Legal Materials in U.S. Constitutional Cases: A Conversation Between Justice Antonin Scalia and Justice Stephen Breyer, 3 INT'L J. Const. L. 519, 541 (2005) (quoting Justice Stephen Breyer) ("Yet I read and refer to treatises and I read and refer to law review articles. My opinion is meant to reflect my actual method of reaching a legal conclusion; and references to those legal materials that had significance and will help the reader understand."). 
may be another way to think about the question, one that relies not on explicit textual commands or prohibitions, but on the implicit invitation to rely on foreign law that inheres in the text's ambiguities. Friedrich Waismann famously observed that language has an "open texture" to it, so that "we can never fill up all the possible gaps through which a doubt may seep in." ${ }^{58} \mathrm{He}$ followed in the footsteps of Ludwig Wittgenstein, ${ }^{59}$ who "believed that when we make an intelligible statement in a language, there is no abstract or 'superlative fact' that can govern the formation of the statement other than the language in which the statement is made." 60

In the legal context, the open-textured nature of language means that rules are often "usable in cases that had not been anticipated by the original legislators, and perhaps even contrary to the legislators' intentions." ${ }^{61}$ Law's open texture derives from the indeterminacy that results from "the judge (or legal community) being unable to give any principled reasons why a particular case ought to be subsumed under one rule rather than another." ${ }^{22}$ H.L.A. Hart wrote that with law, as with language in general, "uncertainty at the borderline is the price to be paid for the use of general classifying terms. ${ }^{" 63}$ When legal formalists attempt

58. Friedrich Waismann, Verifiability, 19 ARISTOTELIAN SOC'Y, SuPPLEMENTARY Volume 119, 123 (1945). See also Jeremy Waldron, Vagueness in Law and Language: Some Philosophical Issues, 82 Cal. L. Rev. 509, 522 (1994) ("A number of philosophers have speculated that vagueness is in principle ineliminable because it is possible to envisage puzzling borderline cases for every predicate we define.").

59. ANDREI MARMOR, INTERPRETATION AND LEGAL THEORY 134 (1992); see also Brian BiX, LAW, LANGUAGE AND Legal DeterminACy 16 (1993) ("Waismann agreed with Wittgenstein that our concepts are not completely defined/fully delimited/completely verifiable, that this 'ideal' could not be reached, and that this 'deficiency' had no negative consequences for our use of language under normal circumstances.") (citations omitted).

60. Anthony J. Sebok, Finding Wittgenstein at the Core of the Rule of Recognition, 52 SMU L. ReV. 75, 92 (1999). See also G.P. BAKER \& P.M.S. HACKeR, WitTGENSTEIN: RUles, GRAMmAR AND NECESSITY 171-72 (1985) ("The pivotal point in Wittgenstein's remarks on following rules is that a rule is internally related to acts which accord with it. The rule and nothing but the rule determines what is correct." (citation omitted)); Ludwig Wittgenstein, Philosophical Investigations $§ 192$ (G.E.M. Anscombe trans., 2d ed. 1958).

61. Steve Fuller, Playing Without a Full Deck: Scientific Realism and the Cognitive Limits of Legal Theory, 97 YALE L.J. 549, 564 (1988).

62. Id.

63. H.L.A. Hart, The CONCEPT OF LAW 128 (3d ed. 2012). 
to "freeze the meaning of the rule so that its general terms must have the same meaning in every case where its application is in question, ${ }^{\prime 64}$ he says,

[they] settl[e] in advance, but also in the dark, issues which can only reasonably be settled when they arise and are identified . . includ[ing] in the scope of a rule cases which we would wish to exclude in order to give effect to reasonable social aims, and which the open-textured terms of our language would have allowed us to exclude, had we left them less rigidly defined. ${ }^{65}$

The Constitution, like many legal texts, uses terms that are very opentextured. ${ }^{66}$ John Hart Ely identifies the Eighth Amendment ${ }^{67}$ as appearing "insistently to call for a reference to sources beyond the document itself," ${ }^{\prime 68}$ and the Ninth and Fourteenth Amendments ${ }^{69}$ as containing "provisions that are difficult to read responsibly as anything other than quite broad invitations to import into the constitutional decision process considerations that will not be found in the language of the amendment." ${ }^{\text {"70 }}$ Similarly, Jack Balkin observes that "[t]he text of our Constitution contains different types of language," including "determinate rules," "standards," and "principles." "W1 Where the text takes the form of determinate rules, an interpreter's discretion is fixed; but where it "uses vague standards or abstract principles, we must apply them to our own circumstances in our own time." 72 The Framers used standards and principles "to channel politics through certain key concepts but delegate the details to future generations"; thus, "fidelity to the Constitution" occasionally "requires future generations to engage in

64. Id. at 129 .

65. Id. at 130 .

66. John Hart Ely, Democracy and Distrust: A TheOry of Judicial ReView $13(1980)$.

67. U.S. CONST. amend. VIII.

68. ELY, supra note 66, at 13.

69. U.S. CONST. amends. IX, XIV.

70. ELY, supra note 66, at 13.

71. JACK BALKIN, LiVING ORIGINALISM 6 (2011).

72. Id. at 7 . 
constitutional construction" "73 - to look beyond the four corners of the document to develop its meaning.

If some constitutional provisions are so textually indeterminate that faithful interpretation will necessarily require recourse to a set of external referents, and if generations subsequent to that of the Framers are textually tasked with filling out the Constitution's meaning on their own, in light of contemporary conditions, then who says foreign law can't be one source of such meaning? Certainly not the text, which, we've noted, is silent as to the propriety of invoking foreign law-not condoning the practice, but not condemning it either. We regularly use dictionaries, law review articles, books, other laws, canons of construction, legislative history, common law terms of art, and colloquial parlance to construe the text of the Constitution-given this rich diversity of sources that we employ, why must foreign law be categorically condemned?

In my view, the best textual argument for the legitimacy of citing foreign law in constitutional argument is not based on an inference that is explicit in the text, but on one rooted in the open-texture of the document as a whole. By failing to specify its own meaning in various places-by using vocabulary, grammar, and semantic form that cannot be given substance without looking to extra-textual sources of meaning-the Constitution's very text invites us to imbue it with something. Its open texture gestures toward referents that lie beyond its borders without defining what those referents must be. Nothing in the text excludes foreign law from the list of candidates. To the extent that we as a society choose to use foreign law as a source of meaning to fill out our constitutional intestacies, the indeterminacy of the text permits us to do so.

\section{B. History}

How would we evaluate the legitimacy of citing foreign law as a matter of history? While various originalisms differ in their exact methodologies, all agree that constitutional questions should be decided in accordance with the original meaning of the relevant constitutional

73. Id. 
provisions. Originalists such as Justice Scalia ${ }^{74}$ and Judge Bork ${ }^{75}$ believe that what matters is "original public meaning," which "can be illuminated by legislative history and by contemporary speeches, articles, and dictionaries." ${ }^{76}$ The interpretive methodology that would have been used by legislators and informed members of the public may also be relevant to an originalist appraisal. ${ }^{77}$ For originalists, the legitimacy of a constitutional practice stems from its conformity to how the Constitution would have been understood at the time of ratification or amendment.

Some, such as Harold Koh, ${ }^{78}$ and Justice Ginsburg ${ }^{79}$ have invoked the language of the Declaration of Independence - specifically, its reference

74. See, e.g., Steven G. Calabresi \& Andrea Matthews, Originalism and Loving v. Virginia, 2012 BYU L. REV. 1393, 1395 (2012) ("Originalists believe that it is the original public meaning of the words of a legal text that govern and not the subjective spin put on that text by members of Congress in the legislative history. In other words, Scalia-style originalists should not concern themselves with original intent.") (citation omitted); William Michael Treanor, Taking Text Too Seriously: Modern Textualism, Original Meaning, and the Case of Amar's Bill of Rights, 106 Mich. L. REV. 487, 49798 (2007) (showing that Justice Scalia uses debate history and then-contemporary political writings in interpreting the Constitution); ANTONIN SCALIA, Common-Law Courts in a Civil-Law System: The Role of United States Federal Courts in Interpreting the Constitution and Laws, in A MATter of InTERPRETATION: Federal Courts AND the LAw 3, 38 (Amy Gutmann ed., 1997) [hereinafter Scalia, Common-Law Courts] (arguing that original meaning should be determined with reference to the understandings of intelligent, informed people of the era); Antonin Scalia, Originalism: The Lesser Evil, 57 U. CIN. L. REV. 849, 856-57 (1989) (asserting that the political and intellectual atmosphere of the Framing Era is dispositive of constitutional meaning).

75. See Robert H. Bork, The Tempting of America: The Political Seduction OF THE LAW 144 (1990) ("If someone found a letter from George Washington to Martha telling her that what he meant by the power to lay taxes was not what other people meant, that would not change our reading of the Constitution in the slightest. . . Law is a public act. Secret reservations or intentions count for nothing. All that counts is how the words used in the Constitution would have been understood at the time.").

76. Steven G. Calabresi \& Julia T. Rickert, Originalism and Sex Discrimination, 90 TeX. L. REV. 1, 4 (2011).

77. John O. McGinnis \& Michael B. Rappaport, Original Methods Originalism: A New Theory of Interpretation and the Case Against Construction, 103 Nw. U. L. REv. 751, 763 (2009) ("Although the public meaning cannot be divorced from word meanings or grammar rules, Barnett never explains why interpretive rules should be treated differently. It is true that the content of these interpretive rules is disputable, but so is the content of word meanings and grammatical rules.").

78. Harold Hongju Koh, Edward L. Barrett, Jr. Lecture on Constitutional Law, 35 U.C. DAvis L. REV. 1085, 1086 (2002) ("The question I want to ask is whether we, as 
to "a decent respect to the opinions of mankind" citation of foreign law accords with the intentions of those who wrote it. ${ }^{81}$ But arguments like this, as Jeremy Waldron observes, amount to little more than the "mouthing [of] platitudes." ${ }^{\prime 2}$ The purpose of that phrase's usage in the Declaration was "not to justify the importation of foreign precedents but to justify requiring American patriots to explain themselves to the world." ${ }^{\circ 3}$

Some defend the practice of citing foreign law by observing that the Framers in fact relied extensively on sources of foreign law as they drafted the Constitution itself. Paul Finkelman notes that delegates to the Constitutional Convention "made numerous references to foreign law and foreign governmental systems." " To give a few examples, the English constitution was described as "admirable," executive compensation were punctuated with Benjamin Franklin's references to "the High Sheriff in England and the French 'office of Counsellor or Member of their Judiciary Parliaments." "86 James Wilson invoked "examples of Turkey, Russia, and Persia to support the idea that the states had to continue to exist, even as they had to be subordinate to the national government" in objecting to the New Jersey Plan. ${ }^{87}$ Another

Americans, pay decent respect to the opinions of humankind in our administration of the death penalty.").

79. See Ruth Bader Ginsburg, "A Decent Respect to the Opinions of [Human]Kind": The Value of a Comparative Perspective in Constitutional Adjudication, 26 AM. U. INT'L L. REV. 927, 930 (2011) ("The drafters and signers of the Declaration of Independence showed their concern about the opinions of other peoples; they placed before the world the reasons why the States, joining together to become the United States of America, were impelled to separate from Great Britain.").

80. The DeClaration OF INDEPENDENCE para. 1 (U.S. 1776).

81. See generally Koh, supra note 78; Ginsburg, supra note 79.

82. Jeremy Waldron, "Partly Laws Common to All Mankind": Foreign LAW IN AMERICAN COURTS 22 (2012).

83. Id.

84. Paul Finkelman, Foreign Law and American Constitutional Interpretation: A Long and Venerable Tradition, 63 N.Y.U. ANN. SuRV. AM. L. 29, 37 (2007).

85. 2 The ReCords of the Federal Convention of 1787, at 278 (Max Farrand ed., Yale Univ. Press rev. ed., 1966) (1911) [hereinafter 2 Farrand].

86. Finkelman, supra note 84, at 38 (citing 1 THE RECORDS OF THE FEDERAL Convention OF 1787, at 84 (Max Farrand ed., Yale Univ. Press rev. ed., 1966) (1911) [hereinafter 1 Farrand]).

87. Id. at 39 (citing 1 Farrand, supra note 86, at 328 ). 
delegate, John Dickinson, relied on Blackstone to understand the phrase "ex post facto." ${ }^{18}$ Such examples are plentiful. ${ }^{89}$

"[I]f Blackstone helped our framers grope their way through difficult issues of their time," Steve Sanders asks, "why should American courts today refuse any help from their global peers as they reason their way through difficult issues of our time?" ${ }^{90}$ But arguments like this probably would not sway most originalists, who would observe that there is an enormous difference between the task of writing a constitution, in which drafters are free to rely for inspiration on whatever sources they please, and the task of interpreting a constitution, ${ }^{91}$ in which faithful participants should try to discern the meaning of the constitution that its Framers actually did create in light of the way it would have been understood at the time. ${ }^{92}$ Justice Scalia himself recognizes that "comparison with the practices of other countries is very useful in devising a constitution. But why is it useful in interpreting one?" ${ }^{93}$ As Scalia has said, "in writing [a constitution], of course you consult foreign sources, see how it has worked, see what they've done, use their examples and so forth. But that has nothing to do with interpreting it." ${ }^{\text {"W }}$ When drafting a constitution, one writes on a clean slate; but by the time one is interpreting a constitution, the slate has been written on, and one's job is to try to the best of one's abilities to read it.

A better originalist argument for citing foreign law might be that, as Steven G. Calabresi and Stephanie Dotson Zimdahl have shown, the Supreme Court cited foreign law numerous times during the era following the Constitution's ratification, ${ }^{95}$ without producing

88. Id. at 40 (citing 2 Farrand, supra note 85, at 448-49).

89. See generally id. at 37-42.

90. Steve Sanders, American Legal Conservatives Oppose the Citation of Foreign Law, But What About the Hallowed Practice of Citing to Blackstone?, FindLAW (Oct. 10, 2008), http://writ.news.findlaw.com/ commentary/20081010_sanders.html.

91. See, e.g., Dorsen, supra note 57, at 538 ("Alexander Hamilton, sir, was writing a Constitution, not interpreting one.").

92. Scalia, Common-Law Courts, supra note 74, at 37-38.

93. Dorsen, supra note 57, at 525.

94. Id. at 538-39.

95. Steven G. Calabresi \& Stephanie Dotson Zimdahl, The Supreme Court and Foreign Sources of Law: Two Hundred Years of Practice and the Juvenile Death Penalty Decision, 47 WM. \& MARY L. REV. 743, 791 (2005) ("We thus conclude that in the first 
contemporaneous backlash to suggest that this practice was considered to be inappropriate at the time, one exception. ${ }^{96}$ Thus, "commentators who say that the Court has never before cited or relied upon foreign law are clearly and demonstrably wrong." 97

Many early decisions citing foreign law were written by Chief Justice Marshall, Calabresi and Zimdahl observe. ${ }^{98}$ In Talbot v. Seeman (1801), ${ }^{99}$ Marshall wrote that "the laws of the United States ought not, if it be avoidable, so to be construed as to infract the common principles and usages of nations, or the general doctrines of national law." ${ }^{100}$ In Murray v. Schooner Charming Betsy (1804), ${ }^{101}$ he asserted that "an act of Congress ought never to be construed to violate the law of nations if any other possible construction remains." ${ }^{102}$ In practice, Calabresi and Zimdahl note, Marshall was instructing courts to "exercise [their] constitutional power [to interpret statutes] by giving legal weight to foreign sources of law." ${ }^{103}$ In Rose v. Himley (1808), ${ }^{104}$ Marshall examined several English cases decided subsequent to American independence, ${ }^{105}$ concluding that " $[\mathrm{t}]$ he manner in which this subject is understood .... is adopted by this court as the true principle which ought

fifty years of Supreme Court history there were references to foreign sources of law by three Justices-Marshall, Story, and Johnson.").

96. See United States v. Smith, 18 U.S. (5 Wheat.) 153, 164-83 (1820) (Livingston, J., dissenting).

97. Calabresi \& Zimdahl, supra note 95, at 755.

98. $I d$. at 763 . See generally $i d$. at $763-80$, for a much more thorough discussion of the cases that follow.

99. Talbot v. Seeman, 5 U.S. (1 Cranch) 1 (1801).

100. Id. at 43 .

101. Murray v. Schooner Charming Betsy, 6 U.S. (2 Cranch) 64 (1804).

102. Id. at 118 .

103. Calabresi \& Zimdahl, supra note 95, at 766.

104. Rose v. Himely, 8 U.S. (4 Cranch) 241 (1808), overruled by Hudson v. Guestier, 10 U.S. (6 Cranch) 281 (1810).

105. Id. at 270-71 (discussing Flad Oyen, (1799) 165 Eng. Rep. 124, 1 C. Rob. 114, 134 (High Ct. Admlty); The Christopher, (1799) 165 Eng. Rep. 291, 2 C. Rob. 173, 209 (High Ct. Admlty); The Henrick and Maria, (1799) 165 Eng. Rep. 129, 1 C. Rob. 35, 146 (High Ct. Admlty); and The Helena, (1801) 165 Eng. Rep. 515, 4 C. Rob. 3 (High Ct. Admlty)); see also Calabresi \& Zimdahl, supra note 95, at 767-68 (discussing Marshall's treatment of these cases). 
to govern in this case." "106 Thus, "foreign law [was] adopted by Chief Justice Marshall as the new American rule of law."107

In Brown v. United States (1814), ${ }^{108}$ Marshall canvassed the views of "famous foreign jurists and writers," 109 and declared that "a construction ought not lightly to be admitted which would give to a declaration of war an effect in this country it does not possess elsewhere." "110 Justice Joseph Story dissented, but he did not object to Marshall's citation of foreign law; his own opinion relied on foreign sources extensively. ${ }^{111}$ In The Antelope (1825), ${ }^{112}$ Marshall observed that the slave trade, though "contrary to the law of nature," "113 had been engaged in by "Christian and civilized nations of the world, with whom we have most intercourse," 114 and that it has been "sanctioned in modern times by the laws of all nations who possess distant colonies, each of whom has engaged in it as a common commercial business which no other could rightfully interrupt." ${ }^{115}$ Marshall also noted Britain's abolition of slavery, ${ }^{116}$ and referred with approval to several British antislavery decisions that had been decided after $1776 .{ }^{117}$

106. Rose v Himely, 8 U.S. (4 Cranch) 241, 271 (1808).

107. Calabresi \& Zimdahl, supra note 95, at 769. The authors note that "[a]dmittedly, this case is an example of the Supreme Court borrowing a rule in an admiralty case from a country closely related to the United States and not one of the Court being influenced by the mores of France or Germany." Id. However, they say, they believe the case "is at least a little disturbing for the thesis that the Supreme Court ought never to look to foreign sources of law." Id.

108. Brown v. United States, 12 U.S. (8 Cranch) 110 (1814).

109. Calabresi \& Zimdahl, supra note 95 , at 770.

110. Brown, 12 U.S. (8 Cranch) at 125.

111. Id. at 132-41 (Story, J., dissenting) (surveying the views of various foreign jurists).

112. The Antelope, 23 U.S. (10 Wheat.) 66 (1825).

113. Id. at 120 .

114. Id. at $114-15$.

115. Id. at 115 .

116. Id. at $115-16$.

117. See The Amedie, (1810) 12 Eng. Rep. 92 (P.C.) 1 Acton 240; The Diana, (1813) 165 Eng. Rep. 1245 (High Ct. Admlty), 1 Dods. 95; and Le Louis, (1817) 165 Eng. Rep. 1464 (High Ct. Admlty), 2 Dods. 210. The Antelope, 23 U.S. (10 Wheat.) at 116-20 (Chief Justice Marshall discussing several of the British antislavery cases after 1776). Calabresi \& Zimdahl, supra note 95, at 775-77 (discussing Marshall's treatment of the antislavery cases after 1776). 
In addition to his abovementioned Brown dissent, ${ }^{118}$ Justice Story also authored the majority opinion in United States v. Smith (1820), ${ }^{119}$ asserting that the law of nations "may be ascertained by consulting the works of jurists, writing professedly on public law; or by the general usage and practice of nations; or by judicial decisions recognising and enforcing that law." ${ }^{20}$ One footnote cited a variety of "foreign jurists and scholars and international practice[s]" by the law of nations." 122 As Calabresi and Zimdahl note, "[t]he Court . . . turned to foreign sources of law to uphold the congressional statute that otherwise might have been found unconstitutional."123 In a dissenting opinion, Justice Livingston argued both that piracy was insufficiently well-defined by the law of nations to justify the imposition of the death penalty, ${ }^{124}$ and that a criminal statute's meaning must be fixed by Congress rather than foreign law. ${ }^{125}$ Story cited foreign law in one other opinion, Columbia Insurance Co. of Alexandria v. Ashby (1839), ${ }^{126}$ in which he canvassed Rhodian law ${ }^{127}$ and the views of foreign jurists. ${ }^{128}$ The final opinion of the era to use foreign law was The Rapid (1814); ${ }^{129}$ among other things, the Court invoked foreign views in "the most enlightened ... commercial nations."

From an originalist perspective, what does this tell us about the legitimacy of using foreign law? One could possibly say 'nothing' - that this is all just post-ratification history, and thus doesn't speak to the

118. Brown v. United States, 12 U.S. (8 Cranch) 110, 129 (Story, J., dissenting).

119. United States v. Smith, 18 U.S. (5 Wheat.) 153, 157 (1820).

120. Id. at $160-61$.

121. Calabresi \& Zimdahl, supra note 95, at 783.

122. Smith, 18 U.S. (5 Wheat.) at 163 n.8.

123. Calabresi \& Zimdahl, supra note 95, at 782.

124. Smith, 18 U.S. (5 Wheat.) at 181 (Livingston, J., dissenting) ("Although it cannot be denied that some writers on the law of nations do declare what acts are deemed piratical, yet it is certain, that they do not all agree.").

125. Id. at 182 (Congress must "incorporate into their own statutes a definition in terms, and not [] refer the citizens of the United States for rules of conduct to the statutes or laws of any foreign country, with which it is not to be presumed that they are acquainted.").

126. Columbia Ins. Co. of Alexandria v. Ashby, 38 U.S. (13 Pet.) 331 (1839).

127. Id. at 337-39.

128. Id. at 339-42.

129. The Rapid, 12 U.S. (8 Cranch) 155 (1814).

130. Id. at 162 . 
understanding of ordinary intelligent and informed people of the framing era. But that doesn't seem right. While these cases were admittedly decided after the Constitution had already been put into effect, it is fair to infer that they reflect the common attitudes concerning the citation of foreign law that prevailed at the time of ratification-after all, Talbot was decided a mere twelve years after $1789 .{ }^{131}$ Surely it would be unreasonable to assume that American attitudes toward the use of foreign law had shifted so drastically in so short a period of time.

More likely, these cases illustrate that the Framing generation did not regard the citation of foreign law - at least for certain types of usage - as negatively as some of the practice's opponents do today. This conclusion is bolstered by the fact that there was seemingly no backlash against the Supreme Court's use of foreign law. Even Livingston's Smith dissent did not purport to condemn the citation of foreign law wholesale-merely this particular usage, where he believed that the law of nations did not define piracy offenses with sufficient specificity, ${ }^{132}$ and where criminal punishment was at stake. ${ }^{133}$ It is also bolstered by the fact that several of the opinions citing foreign law were written by the legendary Chief Justice John Marshall and Justice Joseph Story. ${ }^{134}$ Within an originalist framework, then, the citation of foreign law-for at least some purposes - has a fair claim to legitimacy.

\section{Doctrine}

How would a doctrinalist approach the question of whether it is legitimate for American courts to invoke foreign law? Professor Bobbitt describes doctrinal appeals as consisting of "neutral, general principle[s]

131. See Talbot v. Seeman, 5 U.S. (1 Cranch) 1 (1801).

132. Smith, 18 U.S. (5 Wheat.) at 181 (Livingston, J., dissenting).

133. Id. ("If in criminal cases every thing is sufficiently certain, which by reference may be rendered so, which was an argument used at bar, it is not perceived why a reference to the laws of China, or to any other foreign code, would not have answered the purpose quite as well as the one which has been resorted to.").

134. Chief Justice Marshall wrote The Antelope, 23 U.S. (10 Wheat.) 66 (1825); Brown v. United States, 12 U.S. (8 Cranch) 110 (1814); Rose v. Himely, 8 U.S. (4 Cranch) 241 (1808); Murray v. Schooner Charming Betsy 6 U.S. (2 Cranch) 64 (1804); and Talbot, 5 U.S. (1 Cranch). Justice Story wrote Columbia Ins. Co. of Alexandria v. Ashby, 38 U.S. (13 Pet.) 331 (1839); and Smith, 18 U.S. (5 Wheat.). 
derived from the caselaw construing the Constitution." ${ }^{135}$ On one level, doctrinalism is all about adherence to precedent. When thought of in this sense, the answer seems immediately apparent: of course American courts can cite foreign law, because they have done so. Calabresi and Zimdahl have demonstrated not only that the Supreme Court cited foreign sources of law with some frequency during the early days of the Republic, but also that it has continued to do so throughout all subsequent epochs of American history. ${ }^{136}$

Doctrinalism locates the source of constitutional legitimacy in what came before-in what had already been done. Unlike the historical modality, in which the older an idea's roots are the more legitimate it is, doctrinalism says that an idea is constitutionally legitimate in proportion to how recently it has found expression in the caselaw. The more recently a judicial decision has been rendered, the greater authority it carries in a subsequent case. This is why today we cite Brown v. Board of Education (1954) ${ }^{137}$ rather than Plessy v. Ferguson (1896), ${ }^{138}$ or Shelby County v. Holder $(2013)^{139}$ rather than South Carolina v. Katzenbach (1966), ${ }^{140}$ or Garcia v. San Antonio Metropolitan Transit Authority $(1985)^{141}$ rather than National League of Cities v. Usery (1976). ${ }^{142}$ Not all precedents are created equal; decisions of more recent vintage outweigh and/or overrule older ones. This is true even where a newer decision does not purport to flatly overrule an older one, but merely modify it. A savvy litigator today would sooner cite Planned Parenthood of Southeastern Pennsylvania v. Casey $(1992)^{143}$ than Roe v. Wade (1973) ${ }^{144}$ on questions concerning abortion - or even better yet, Gonzales v. Carhart (2007). ${ }^{145}$

135. BoBBIT, supra note 6, at 17-18.

136. See Calabresi \& Zimdahl, supra note 95.

137. Brown v. Bd. of Educ., 347 U.S. 483 (1954).

138. Plessy v. Ferguson, 163 U.S. 537 (1896).

139. Shelby Cnty. v. Holder, 133 S. Ct. 2612 (2013).

140. South Carolina v. Katzenbach, 383 U.S. 301 (1966).

141. Garcia v. San Antonio Metro. Transit Auth., 469 U.S. 528 (1985).

142. Nat'l League of Cities v. Usery, 426 U.S. 833 (1976).

143. Planned Parenthood of Se. Pa. v. Casey, 505 U.S. 833 (1992).

144. Roe v. Wade, 410 U.S. 113 (1973).

145. Gonzalez v. Carhart, 550 U.S. 124, (2007). 
With respect to the scope of the treaty power, ${ }^{146}$ meanwhile, she would rather cite Bond v. United States (2014) ${ }^{147}$ than Missouri v. Holland (1920)..$^{148}$

Thus, all that a doctrinalist might need to satisfy herself that the citation of foreign law is a legitimate constitutional practice, at least for some purposes, is to observe that in recent years, the Supreme Court has repeatedly cited foreign law. Since 1997, the Court has invoked foreign law in Roper v. Simmons (2005), ${ }^{149}$ Lawrence v. Texas (2003), ${ }^{150}$ Atkins v. Virginia (2002), ${ }^{151}$ and, in one of the rarer examples of foreign law's invocation to reach a conservative decision, Washington v. Glucksberg (1997). ${ }^{152}$ It is important to note that that these decisions all endorsed the citation of foreign law only for a certain purpose, however-as persuasive, rather than binding, authority. ${ }^{153}$ None of the recent cases suggest that foreign law qua foreign law is binding on American courts or displaces what would otherwise be the appropriate rule of decision. ${ }^{154}$ This suggests that there is good doctrinal support only for the legitimacy of citing foreign law as persuasive authority.

146. U.S. CONST. art. II, § 2, cl. 2 ("[The President] shall have Power, by and with the Advice and Consent of the Senate, to make Treaties, provided two thirds of the Senators present concur ....”).

147. Bond v. United States, 134 S. Ct. 2077 (2014).

148. Missouri v. Holland, 252 U.S. 416 (1920).

149. Roper v. Simmons, 543 U.S. 551, 575-78 (2005).

150. Lawrence v. Texas, 539 U.S. 558, 572-73, 576-77 (2003).

151. Atkins v. Virginia, 536 U.S. 304, 316-17 n.21 (2002).

152. Washington v. Glucksberg, 521 U.S. 702, 717-18 nn.15-16, 730, 732, 74353 (1997).

153. See case excerpts cited supra notes 149-152.

154. For example, Lawrence invoked foreign law to disprove the argument, made in Bowers v. Hardwick, that " [c] condemnation of [homosexual] practices is firmly rooted in Judeao-Christian moral and ethical standards." Lawrence, 539 U.S. at 571-73 quoting Bowers v. Hardwick, 478 U.S. 186, 196, (1986), overruled by Lawrence, 539 U.S. 558. Likewise, Glucksberg invoked the Dutch experience with euthanasia to substantiate concerns that the practice may be abused in "cases involving vulnerable persons." Glucksberg, 521 U.S. at 734. In both cases, the Court cited foreign law for a limited, discrete purpose, not to constitute the basis of its analysis. Likewise, in Roper, the Court invoked foreign law to establish the existence of a consensus against the imposition of the death penalty for juveniles, but explicitly noted that "[t]he opinion of the world community [is] not controlling our outcome," but merely "provide[s] respected and significant confirmation for our own conclusions." 543 U.S. at 578. 
But there is also another sense in which doctrinal concerns may bear on how we understand the legitimacy of citing foreign law. Doctrinalism is about more than just the rote, mechanistic application of good judicial precedents; on a deeper level, it is about consistent, principled decisionmaking. The essence of doctrinalism lies in "announcing a general principle applicable to a larger class," $" 155$ and then applying that principle to the facts at hand; what matters are "neutral principles of general application." ${ }^{" 156}$ H.L.A. Hart once criticized the collective Supreme Court decisions from the prior term on the grounds that they "lack[ed] the underpinning of principle which is necessary to . . exemplify . . . the rule of law." 157 According to Bobbitt, "only such opinions will be legitimate." $" 158$

This search for consistent, principled, uniform legal decision-making is echoed in Jeremy Waldron's jurisprudential justification for citing foreign law, which rests on notions of "consistency, harmonization, and integrity," of "treating like cases alike."159 The claim is that we ought to cite foreign law in order to harmonize our law with that of other nations in order to achieve transnational consistency, because, as Waldron says, "[w]e are bound into a global community, especially on questions of fundamental rights, and we cannot ignore the concerns about fairness and evenhandedness that might arise in the world on that basis." 160 If you think that there are certain things that are just plain law across the globe, no matter where you are, then citing foreign law to bring American law into harmony with the law of other nations has a doctrinal purpose.

To accept this type of argument, one would have to accept that there is "a body of jurisprudence constituted jointly by a consistency among decisions in the world that could be held out as a resource." 161 It is on this belief that Waldron justifies the citation of foreign law, the belief that there are "deep background principles, legal principles, [that] may be

155. BoBBiTt, supra note 5, at 46-47.

156. Id. at 42 .

157. Henry M. Hart, The Supreme Court, 1958 Term-Foreword: The Time Chart of the Justices, 73 HARV. L. REV. 84, 99 (1959) (lower courts can apply "[o]nly opinions which are grounded in reason.").

158. Philip Bobbitt, Constitutional Fate, 58 TEX. L. REv. 695, 714 (1980).

159. WALDRON, supra note 82, at 141.

160. Id.

161. Id. at 67. 
inferred not just from a single existing body of positive law . . but also from multiple legal systems taken together." 162 The idea is not that foreign law is binding on us qua foreign law, but rather that the recurring presence of certain norms in foreign legal sources indicates, as a clue, that a norm just inheres it what it means for something to be law. ${ }^{163}$

This is the sort of reasoning that is implicit in the famous New York Court of Appeals decision Riggs v. Palmer (1889), ${ }^{164}$ which Waldron discusses in fleshing out his argument. ${ }^{165}$ A 16-year-old man killed his grandfather and then sought to inherit property that was willed to him. ${ }^{166}$ Notwithstanding what appeared to be the plain, literal letter of state statutes on the subject of wills, ${ }^{167}$ the court held that the man could not inherit. ${ }^{168}$ Instead, it reasoned that "all laws as well as all contracts may be controlled in their operation and effect by general, fundamental maxims of the common law." " "[n]o one shall be permitted to profit by his own fraud, or to take advantage of his own wrong, or to found any claim upon his own iniquity, or to acquire property by his own crime." 170 Significantly, the court asserted that "[t]hese maxims ... have their foundation in universal law administered in all civilized countries." 171 It then cited the Code Napoléon, ${ }^{172}$ the Civil Code of Lower Canada, ${ }^{173}$ and Roman law ${ }^{174}$ in support of the general legal proposition - that no one may profit by his crime - that it had just recognized.

162. Id. (emphasis added).

163. See id. ("Indeed, principles whose presence may not be so apparent in one system may come more clearly into view when we look at a whole array of legal systems.").

164. Riggs v. Palmer, 22 N.E. 188 (N.Y. 1889).

165. See WALDRON, supra note 82, at 62-67.

166. Riggs, 22 N.E. at 189.

167. Id. ("It is quite true that statutes regulating the making, proof, and effect of wills and the devolution of property, if literally construed, and if their force and effect can in no way and under no circumstances be controlled or modified, give this property to the murderer.").

168. Id. at 191.

169. Id. at 190 .

170. Id.

171. Id. (emphasis added).

172. Id.

173. Id.

174. Id. 
The New York Court of Appeals wasn't using foreign law to displace New York law; it was saying that certain universal principles were already part of state law by virtue of their global ubiquity, and used foreign law merely to illustrate or illuminate these principles. ${ }^{175}$ If one accepts that we are a "participant[] in a common judicial enterprise . . . [part of] a community with identifiable organizing principles," $" 176$ then citing foreign law in this sort of way is legitimated by doctrinal need for legal consistency at a global scale. "[J]ust as fire burns in Persia as well as in Greece, so murder is wrong in Carthage and in Rome." 177

On the other hand, this global-doctrinalism can run the other way as well - counseling against the use of foreign law-in at least two important ways. The first is that inviting American courts to invoke foreign law as they please without also instructing them to articulate some "jurisprudence which explains what they are doing in this regard" 178 - to adhere to some sort of "theory of law" that will "explain why American courts are legally permitted or obligated to invoke nonAmerican sources and how that practice connects with the status of courts as legal institutions" "-would make "inconsistent and unprincipled citation" virtually "inevitable." " In part, this would result simply from the fact that it would be very difficult to articulate any principled set or rules or standards to govern the citation of foreign law that could account for the innumerable differences between and variations among all of the world's judiciaries. As Judge Richard Posner notes, "[t]he judicial systems of the United States are relatively uniform, and their product readily accessible, while the judicial systems of the rest

175. Id. at 190 ("[A]1l laws . . may be controlled in their operation and effect by general, fundamental maxims of the common law ... . [which] are dictated by public policy, have their foundation in universal law administered in all civilized countries, and have nowhere been superseded by statutes.").

176. ANNE-MARIE Slaughter, A New World Order 68 (2004).

177. WALDRON, supra note 82 , at 134 . Waldron is alluding to Aristotle, who wrote: "In the opinion of some people, all [just things] are of this character, because what is by nature is unchangeable and has the same capacity everywhere, just as fire burns both here and in Persia, whereas they see the just things being changed." ARISTOTLE, Aristotle's Nicomachean Ethics 105 (Robert C. Bartlett \& Susan D. Collins trans. 2011).

178. Id. at 21 .

179. Id. at 22 .

180. Id. at 23 . 
of the world are immensely varied and most of their decisions inaccessible, as a practical matter, to our monolingual judges and law clerks." ${ }^{\prime 181}$ American courts are also ill-equipped to understand, much less account for, the "complex socio-historico-politico-institutional background[s]" from which foreign decisions emerge, of which, Posner asserts, "our judges . . . are almost entirely ignorant." "182 Justice Scalia also expresses this concern, saying that "[o]ne of the difficulties of using foreign law is that you don't understand what the surrounding jurisprudence is." 183

This, in turn, would give rise to another problem: namely, a proliferation of opportunities for cynical, opportunistic, unprincipled citation. "If foreign decisions were freely citable," Posner says, "it would mean that any judge wanting a supporting citation had only to troll deeply enough in the world's corpus juris to find it." ${ }^{184}$ Justice Scalia gives voice to this concern in his Roper dissent ${ }^{185}$ - the fear that American judges will selectively invoke foreign law to mask their own policy preferences. "To invoke alien law when it agrees with one's own thinking, and ignore it otherwise, is not reasoned decisionmaking," Scalia thunders, "but sophistry." 186 Later, Scalia says: "What these foreign sources 'affirm,' . . . is the Justices' own notion of how the world ought to be, and their diktat that it shall be so henceforth in America." 187 He has a point. As Scalia has said, citation of foreign law in this manner "lends itself to manipulation. It invites manipulation." 188 Using foreign law without some organized body of standards to guide you is "akin to

181. Richard Posner, No Thanks, We Already Have Our Own Laws, LEGAL AfFAirs (July-Aug. 2013),

www.legalaffairs.org/issues/July-August-2004/feature_posner_julaug04.msp.

182. Id.

183. Dorsen, supra note 57, at 528.

184. Posner, supra note 181.

185. Roper v. Simmons, 543 U.S. 551, 624-27 (2005) (Scalia, J., dissenting) (listing jurisprudential domains in which the Court has declined to follow the examples of foreign countries, including abortion, the exclusion of improperly-obtained evidence, and state endorsement of religion).

186. Id. at 627 .

187. Id. at 628 .

188. Dorsen, supra note 57, at 531. Cf. Lawrence v. Texas, 539 U.S. 558, 587-92 (2003) (Scalia, J., dissenting) (criticizing the Court's pattern of reliance on or departure from precedent as unprincipled); Planned Parenthood of Se. Pa. v. Casey, 505 U.S. 833, 982, 992-93 (1992) (Scalia, J., dissenting). 
'looking over a crowd and picking out your friends."'189 Judge Frank Easterbrook just assumes that this is what the Court was doing in several recent cases in which it cited foreign law, declaring himself "inclined to think that these references are just window dressing." $" 190$

Of course, the proper response might be that judges already have a more than sufficient arsenal of tools to codify their personal ideological, prudential or aesthetic preferences into law, and so preventing them from using foreign law won't change a thing. As Judge Michael Kirby of the High Court of Australia said, "if you're just going to pick out the ideas and reasoning that you like, if you're going to shove them in your opinions, and give what you wrote decoration, well, that's dishonest." 191 So what? "If judges want to be dishonest, then they'll be dishonest.". 192 This suggests that judges should not use foreign law without having first articulated a theory about why and when it is permissible to invoke it, lest they be tempted to cite it in an unprincipled way.

The second way to object to the use of foreign law on global-doctrinal grounds is to reject the premise that we have any need to unify our law with that of other countries outright. If one does not believe that we are "bound into a global community,"193 then there is simply very little need for any legal uniformity between nations. What happens here is not the same as what happens there, for many reasons, and therefore there is no doctrinal need to reconcile the two. Or as Justice Scalia says, "we don't have the same moral and legal framework as the rest of the world, and never have." 194 Therefore, "it is quite impossible for French practice to be useful in determining the evolving standards of decency of American society." 195 Put more bluntly: "[W]hat does the opinion of a wise

189. Patricia M. Wald, Some Observations on the Use of Legislative History in the 1981 Supreme Court Term, 68 IowA L. REV. 195, 214 (1983).

190. Easterbrook, supra note 2, at 224-25.

Ask yourself this: if some countries prosecute newspapers that publish caricatures of the Prophet Muhammad, or imprison historians who deny that the Holocaust occurred (as Austria has done), what is the chance that any Justice of the Supreme Court will cite these steps as precedent in any case under the First Amendment of our Constitution? There is no chance.

191. Michael Kirby, Citation of Foreign Decisions in Constitutional Adjudication, 43 Suffolk U. L. ReV. 149, 153 (2009).

192. Id.

193. WALDRON, supra note 82, at 141.

194. Dorsen, supra note 57, at 521 (emphasis in original).

195. Id. at 526. 
Zimbabwe judge or a wise member of a House of Lords law committee - what does that have to do with what Americans believe?" 196

In sum, the citation of foreign law as persuasive authority is certainly legitimate to the extent that legitimacy is derived from adherence to fairly recent judicial precedents, although there is little basis to claim that it would be likewise legitimate to cite foreign law as binding authority. On a more global scale, the practice is either legitimate or illegitimate based on whether you perceive a need to integrate American law into a larger body of transnational law. I imagine that most Americans would emphatically disagree that such a need exists. But again, this only means that we need to reject foreign law as a source of binding authority-it does not mean we cannot cite it for persuasive purposes.

\section{Prudence}

The prudential argument for the legitimacy of citing foreign law seems straightforward at first, but as we will see, there are compelling prudential arguments against the practice that its supporters might not recognize at first. Prudential argument can be thought of as being concerned with the best way to vindicate constitutional values in the real world. Prudential appeals, Bobbitt says, "are efforts to bring to constitutional decisionmaking "the impact of actuality.",197

The straightforward argument for citing foreign law a prudentialist might offer is that foreign decisions may contain truths, knowledge or information about facts of the world that are relevant to an American judge. To decide any case, a judge needs to know certain things about the world; statutes and case law cannot be used to resolve legal disputes unless on their own, they must be applied to the facts at hand. This is so obvious that it almost seems silly to say so. Sometimes these are empirical facts - where was the person at the relevant time, who owned the thing, what is the thing, etc.

Sometimes, these are facts about what sort of consequences follow from the establishment of certain legal regimes, or from the application of certain legal rules. This was the sense in which Chief Justice

196. Id. at 529 .

197. BobBitT, supra note 5, at 66 (quoting Felix Frankfurter, A Note on Advisory Opinions, 37 HARV. L. REV. 1002, 1006 (1924)). 
Rehnquist cited foreign law in Glucksberg, ${ }^{198}$ acknowledging the troublesome consequences that might accompany legalized euthanasia by invoking the Netherland's experience. Think too of Justice Breyer's dissent in Printz v. United States (1997), ${ }^{199}$ which observed that Switzerland, Germany and the Netherlands all task constituent states with implementing federal programs ${ }^{200}$ on the belief that "such a system interferes less, not more, with the independent authority of the 'state,' member nation, or other subsidiary government, and helps to safeguard individual liberty as well." ${ }^{201} \mathrm{He}$ uses these European experiences to conclude that "there is no need to interpret the Constitution as containing an absolute principle" 202 - here, a prohibition on federal commandeering of state executive officials. ${ }^{203}$

Indeed, one line from Breyer's opinion encapsulates the prudential argument for citing foreign law as well as anybody could: while acknowledging that "there may be relevant political and structural differences between their systems and our own," he nonetheless asserts that "their experience may nonetheless cast an empirical light on the consequences of different solutions to a common legal problem."204 Breyer, who has elsewhere defended the practice of citing foreign law, has expressed the following belief,

[foreign] cases sometimes involve a human being working as a judge concerned with a legal problem, often similar to problems that arise here, which problem involves the application of a legal text, often similar to the text of our own Constitution, seeking to protect certain basic human rights, often similar to the rights that our own Constitution seeks to protect. ${ }^{205}$

Breyer asks, "[i]f I have a difficult case and a human being called a judge, though of a different country, has had to consider a similar problem, why should I not read what that judge has said? It will not bind

198. Washington v. Glucksberg, 521 U.S. 702, 734-35 (1997).

199. Printz v. U.S., 521 U.S. 898 (1997).

200. Id. at 976 (Breyer, J., dissenting).

201. Id. at $976-77$.

202. Id. at 977.

203. Id.

204. $I d$.

205. Dorsen, supra note 57, at 523. 
me, but I may learn something." ${ }^{206}$ This is the prudential argument for the legitimacy of citing foreign law in a nutshell.

Finally, the facts with which a judge may want to be acquainted may be distinctly moral sorts of facts. In Lawrence, the Court cited foreign law to show that disapproval of homosexuality is not a value universally adopted in "wider civilization" 207 and that the right being asserted "has been accepted as an integral part of human freedom in many other countries." 208 Roper likewise cited foreign law to demonstrate the existence of a virtually universal global repulsion toward executing children. ${ }^{209}$ This case offers an especially-apt example of the prudential citation of foreign law to purportedly illustrate, rather than create, a value internal to the U.S. Constitution; the Court expressly claims that "the express affirmation of certain fundamental rights by other nations and peoples simply underscores the centrality of those same rights within our own heritage of freedom." 210 Atkins similarly invoked foreign legal materials to illustrate "a much broader social . . consensus" 211 regarding the execution of the mentally-ill. It highlighted a brief submitted on behalf of the European Union to demonstrate "overwhelming disapprov[al]" of the practice "within the world community." 212 Thus, although Joan Larsen was speaking disparagingly when she referred to the Court's citation of foreign law as equivalent to "moral factfinding," 213 she was in fact on to something.

If you are not satisfied with this information-acquisition argument for citing foreign law, a more sophisticated prudential account of the practice is also available. F.A. Hayek has argued that "[s]pontaneous systems of order are able to absorb and to utilize large quantities of dispersed knowledge to reach better outcomes than any planner could

206. Id.

207. Lawrence v. Texas, 539, U.S. 558, 576 (2003).

208. Id. at 577.

209. Roper v. Simmons, 543 U.S. 551, 575-78 (2005).

210. Id. at 578 .

211. Atkins v. Virginia, 536 U.S. 304, 316 n.21 (2002).

212. Id.

213. Joan L. Larsen, Importing Constitutional Norms from a "Wider Civilization": Lawrence and the Rehnquist Court's Use of Foreign and International Law in Domestic Constitutional Interpretation, 65 Оніо ST. L.J. 1283, 1293 (2004). 
preordain and design." 14 Says Hayek: "[O]ne of the ways in which civilization helps us to overcome th[e] limitation on the extent of individual knowledge is by conquering ignorance, not by the acquisition of more knowledge, but by the utilization of knowledge which is and remains widely dispersed among individuals." 215 If this is true, then a legal system that looks to foreign sources of law "may thus be smart in the way that free markets are smart." 216 Just as markets "enable[] each individual to gain from the skill and knowledge of others whom he need not even know and whose aims could be wholly different from his own" ${ }^{217}$ citing foreign law, by "borrowing or perusing the works of other competent courts[,] . . . allows a court to outsource the intellectual labor necessary to reach a fuller understanding of the issue then before it." ${ }^{218}$

Citing foreign law is symptomatic of "a spontaneous system of order,"219 growing "independently in different courts in sovereign nation states all over the world, unguided by any global sovereign or supreme court proclaiming it." 220 It "constantly adapts itself, and functions through adapting itself, to millions of facts which in their entirety are not known to anybody." 221 In this way, "it may be information and knowledge superior in the way that a market is superior to a Soviet-style planned economy.",222

Of course, one simplistic prudential basis for objecting to the citation of foreign law might be that you think cases like Roper, ${ }^{223}$ Lawrence, ${ }^{224}$

214. Steven G. Calabresi \& Bradley Silverman, Hayek and the Citation of Foreign Law, 2015 Mich. St. L. Rev. 1, 68 (2015) (citing Friedrich A. HayeK, Law, LEGISLATION AND LIBERTY: RULES AND ORDER 15 (1973)).

215. HAYEK, supra note 214.

216. Calabresi \& Silverman, supra note 214, at 69.

217. Friedrich A. Hayek, Law, Legislation and Liberty: The Mirage of SOCIAL JUSTICE 109 (1976).

218. Calabresi \& Silverman, supra note 214, at 69.

219. Id. at 65 .

220. Id.

221. HAYEK, supra note 214, at 13.

222. Calabresi \& Silverman, supra note 214, at 65 (citing HAYEK, supra note 214, at 116). In centrally-planned economies, unlike free market systems, prices don't "serve . . . as indicators of what ought to be done in the present circumstances." HAYEK, supra note 214 , at 116 .

223. Roper v. Simmons, 543 U.S. 551 (2005).

224. Lawrence v. Texas, 539 U.S. 558 (2003). 
Atkins, ${ }^{225}$ and/or Glucksberg ${ }^{226}$ were decided wrongly, and you therefore reject the practice on the grounds that it leads to bad outcomes. A more sophisticated version of this critique would be that the information that domestic courts get from foreign law is bad information, or else is categorically inapplicable to American jurisprudence. This is what Justice Scalia is getting at when he asks "[o]f what conceivable value as indicative of American standards of decency would foreign law be?"227 $\mathrm{He}$ believes that the only way in which foreign law can give judges useful information is if they believe that what they are looking for is "the best answer to this social question in my judgment as an intelligent person, ${ }^{228}$ an approach he rejects. ${ }^{229}$

Another prudential argument against citing foreign law is that the practice encourages judges to invalidate laws whose fate ought to be decided through political, not judicial, processes. Prudentialists recognize that "a court's first responsibility is to decide whether it should decide," 230 and believe that it "should avoid constitutional decision in order to safeguard [its] own position and to activate the political processes of the legislature." ${ }^{231}$ Justice Brandeis once said that "[t]he most important thing we do is not doing." ${ }^{232}$ According to Bobbitt, a prudentialist would believe that "by prudently avoiding some controversies and by handling others in subtle, indirect ways the Court could preserve its independence and authority for those few cases that should be decided on the merits. ${ }^{, 233}$ When it comes to deciding politically-charged controversies, prudentialists believe that less is often more.

Judge Frank Easterbrook eloquently articulates the prudential objection to citing foreign law. He says that the problem with the

225. Atkins v. Virginia, 536 U.S. 304 (2002).

226. Washington v. Glucksberg, 521 U.S. 702 (1997).

227. Dorsen, supra note 57, at 526.

228. Id.

229. Id.

230. BoввIтT, supra note 5, at 63.

231. Id.

232. Alexander M. Bickel, The Unpublished Opinions of Mr. Justice BRANDEIS 17 (1967) (quoting Louis D. Brandeis \& Felix Frankfurter, Manuscript of the Brandeis-Frankfurter Conversations (transcript available at the Harvard Law School Library)).

233. BoвBITT, supra note 5, at 68 . 
Supreme Court's citation of foreign law isn't that the Justices are undermining American sovereignty, but that they "have taken a kingly role for themselves." 234 Too often, he says, judges "start with the belief that the judiciary will flesh out vague rules." 235 They assume that "(a) there is no answer to be found in the Constitution's own text and history, but (b) the judiciary must give an answer. When those conditions hold, people search far and wide." ${ }^{236}$ But when there is no answer to be found in constitutional text and history, strict constructionists might argue, the judiciary not only needn't give an answer, but mustn't. ${ }^{237}$ Says Easterbrook: "the Constitution is higher law and constrains the democratic process. But the emphasis in this phrase must be on the word 'law,' not on the word 'constrains.",238

Easterbrook's main problem with citing foreign law is that it is a manifestation of expression of the Court's over-willingness to resolve disputes that ought not be settled judicially. ${ }^{239}$ Foreign law may not be the cause of this problem, but it is another tool to which they have recourse when meddling in issues they have no business entertaining. As Easterbrook puts it:

Judges who deny that fundamental nature of our political system may be inclined to cite foreign authorities, but that is the least of their sins. The disease lies in the claim of power; foreign citations are just a symptom. . . . My objection is not to the sources the judge chooses to cite but to the legal perspective that makes them pertinent. ${ }^{240}$

234. Easterbrook, supra note 2, at 224.

235. Id. at 226 .

236. Id.

237. See id. ("But when do those conditions hold? The answer should be 'never."').

238. Id. at 227 .

239. Id. at 228 ("Foreign law post-dating the Constitution's adoption is relevant only to those who suppose that judges can change the Constitution or make new political decisions in its name, which I think just knocks out the basis of judicial review. My objection is not to the sources the judge chooses to cite but to the legal perspective that makes them pertinent.").

240. Id. at 228 . 
E. Structure

It is much more difficult to legitimate the practice of citing foreign law on structural grounds than on textual, historical, doctrinal, or prudential grounds. One might be tempted to finger Breyer's Printz dissent as an example of using foreign law within the structuralist modality. ${ }^{241}$ Breyer contrasted the federal system of the United States with those of Switzerland, Germany, and the European Union, asserting that "[a]t least some other countries, facing the same basic problem, have found that local control is better maintained through application of a principle that is the direct opposite of the principle the majority derives from the silence of our Constitution." ${ }^{242}$ Breyer's move here can be described as using foreign law in a way that bears on constitutional structure.

But this thinking confuses the usefulness of citing foreign law with its legitimacy. It may well be the case that foreign legal materials can be useful tools for doing structural analysis, but that is not the question; it is whether the practice of citing foreign law is legitimate as a structural matter. Just as the citation of foreign law may not lend itself to a particular modal use but still be legitimate within that modal form, so may it be lend itself to a modal use but not be legitimate as a matter of that modality.

In a way, the technique of structural argument - the logical inferences that pulse through it, the grammar it employs - is even more deeply internal to a particular constitution than even arguments from the text itself. Language is inherently contextual, because words lack objective significance that exists independently of how they are used in relation to other words, and to the referents that speakers and listeners use to interpret them. ${ }^{243}$ To understand the meaning that the words in a snippet of text convey, one must first understand some referent or set of referents that are external to the text; it is only that referent or set of referents that gives content to the words.

In contrast, structural appeals do not seem to depend on external referents in the way that textual appeals do. While texts must necessarily

241. Printz v. United States, 521 U.S. 898, 976-78 (1997) (Breyer, J., dissenting).

242. Id. at 976 .

243. Supra Part II.A. 
be given content by sources of meaning that are external to them, structural argument is about drawing inferences from other parts of the Constitution itself. Textualists use dictionaries, canons of construction, legislative history, and so on to elucidate constitutional meaning, but structuralists derive constitutional truths solely from the various interior structures and relationships that the Constitution establishes. Because the set of referents that structuralists use to understand the Constitution is internal to the Constitution, there is less if any room for reliance on or utilization of external referents such as foreign law. In this way, structuralism is a closed universe; it is more self-contained than textualism is. At the very least, it does not seem to invite importation of external sources of meaning in the way that textualism does.

And in fact, there are a number of structural arguments that can be made against the citation of foreign law. Bobbitt refers to "the electorate's assigned central role in the federal government" as one of the "structural facts from the relationships among which one may infer certain constitutional rules." 244 Another such structural fact is the "structure of citizenship." 245 Chief Justice Warren wrote that "[t]his Government was born of its citizens, it maintains itself in a continuing relationship with them, and, in my judgment, it is without power to sever the relationship that gives rise to its existence." ${ }^{246}$ Bobbitt understands Warren's assertion to "stand for the proposition that because the relationship between citizen and government is a fundamental structural relationship, it cannot be altered in any substantial way whatsoever except by the constitutionally established means of changing the structure itself by amendment." ${ }^{247}$ Essential to the structure of citizenship is thus the "axiomatic[]" notion "that government does not have the power to unilaterally dissolve the bonds of citizenship."248

What does this have to do with the citation of foreign law? Well, just as "Article I provides the link between government operations and the democratic mandate by requiring that all funding take place by statutes, that is, by the actions of persons who can be turned out by the voters

244. BoBBitT, supra note 5, at 79.

245. Id. at 85 .

246. Perez v. Brownell, 356 U.S. 44, 64 (1957) (Warren, C.J., dissenting).

247. BoвBIT, supra note 5, at 87.

248. Id. at 88 . 
every biennium," 249 so can it be argued that Article III-which vests the federal judiciary with jurisdiction over all cases "arising under this Constitution, the Laws of the United States, and Treaties made, or which shall be made, under their Authority" ${ }^{250}$ — creates a link between judicial operations and the democratic mandate by requiring that all "Cases" ${ }^{251}$ be decided on the basis of rules by which the people, acting through democratic channels, chose to be governed. When courts rely on foreign law, which the people had no hand in crafting, they weaken if not break this democratic link. This isn't a jingoistic or nationalistic argument, it is a structural one.

Just as "the system of representative government would be circumvented" were it that "government operations could be funded without statutory action," 252 so would it be arguably undermined if courts could apply laws that had not been approved by the American people as rules of decision in cases before them. With respect to government funding, Bobbitt says that "the Constitution provides a crucial link between the citizens of the democracy and the actions of the government in a way that is calculated to engage the attention of a busy and preoccupied people[:] . . . oversight of how their money is being spent." "253 Well, oversight of the legal rules in the balance of which hang one's "life, liberty, or property" 254 also seems like a link calculated to grab the people's attention-you'll pay closer attention to the behavior of your lawmakers if their actions determine whether or not you get to keep your property, go to jail, or even live. To the extent that the citation of foreign law undermines this link, it is structurally illegitimate.

In the "American system . . . the people and not the state are sovereign." "255 We hold elections, and they are "messy and tedious," 256 but the winners get to govern for two years, four, or six years. Though the victors "are not bound by their campaign promises . . . they will have

249. Bоввітт, supra note 6 , at 72 .

250. U.S. CONST. art. III, § 2, cl. 1.

251. Id.

252. BoBBITT, supra note 6 , at 72 .

253. Id.

254. U.S. CONST. amend. V.

255. BовBITT, supra note 6, at 73 .

256. Id. 
to defend their actions at the next election." 257 But what if "the discussions of an important issue, pro and con, were simply a sham[?]"258 What if "some position unknown to the candidates and to the public was the real policy being pursued by the government[?]"259 Well, as Bobbitt says, "[t]he entire system is thus subverted. Elections and public discourse would be simply irrelevant, although only a few would know this." ${ }^{260}$ Something like this can be said to happen whenever a court cites foreign law. When courts invoke foreign law, they are invoking law that the American people did not democratically choose for themselves. The democratic political process is less relevant to the degree that courts won't rely exclusively on the laws that it produces anyway. What is the point of even writing your own constitution if your courts are just going to end up using someone else's in the end anyway?

Another structural inference can be drawn from the language of the Tenth Amendment, which reads: "The powers not delegated to the United States by the Constitution, nor prohibited by it to the States, are reserved to the States respectively, or to the people."261 From this language a rough diagram of constitutional decision-makers can be sketched: the people delegate some finite amount of their powers to the federal government, then delegate some finite amount of the remainder to the states, then keep the rest for themselves. The federal government, the states, and the people; these are the actors who exercise constitutional judgment. Under our constitutional structure, foreign law simply forms no part of our legal system. Foreign actors are not to exercise constitutional decision-making power on our behalf.

A final structural inference can be drawn from the existence of the treaty-making power ${ }^{262}$ and the power " $[\mathrm{t}] \mathrm{o}$ define and punish piracies and felonies committed on the high seas, and offenses against the law of nations." 263 The Treaty, Piracy, and Law of Nations Clauses can be said

257. Id. at 74 .

258. Id.

259. Id.

260. Id.

261. U.S. CONST. amend. X.

262. Id. art. II, $\S 2, \mathrm{cl} .2$ (The president "shall have power, by and with the advice and consent of the Senate, to make treaties, provided two thirds of the Senators present concur.").

263. Id. at art. I, $\S 8$, cl. 10 . 
to illustrate the only constitutionally-established relationship that exists between the American people and foreign or international sources of law - a consensual relationship, in which the people democratically choose whether and the extent to which we wish to be governed by foreign law. Then consensual element is lacking, to some degree, when life-tenured judges impose rules on us that rely on foreign law. The Constitution seemingly contemplates that foreign law is only binding on us when we have chosen to be so bound. We don't consent to foreign law.

On a deep level, these structural arguments against the legitimacy of citing foreign law make intuitive sense; this is what people mean when they say that foreign law is not our law, or that it is not a part of our law. It is important to bear in mind, however, that this type of argument only counsels against a particular way of citing foreign law; namely, using it as if it were our own law. But again, this is the great straw manvirtually no one actually thinks courts ought to apply foreign law as the rule of decision in a case and displace existing American law. The argument is usually much more modest: that foreign law can sometimes be helpful for understanding and interpreting what is, fundamentally, American law. Structural argument may simply have nothing to say about this sort of invocation of American law. At the very least, the structural logic that counsels against citing foreign law is substantially weakened when foreign law is being invoked in a persuasive, rather than binding, fashion. Structuralism doesn't seem to compel this usage of foreign law, but nor does it seem to prohibit it.

Finally, while there may not be a strong structural argument in favor of citing foreign law, there is a clear separation of powers argument against allowing Congress to forbid the courts from using it. "It is emphatically the province and duty of the judicial department to say what the law is," ${ }^{264}$ and Congress has no business telling the judicial department how to go about doing its job. Thus, one may conclude, as a structural matter that courts shouldn't use foreign law, but also that if they do, Congress shouldn't do anything about it, like the political question doctrine in reverse. ${ }^{265}$

264. Marbury v. Madison, 5 U.S. (1 Cranch.) 137, 177 (1803).

265. See generally Baker v. Carr, 369 U.S. 186 (1962); Luther v. Borden, 48 U.S. 1 (1849). 
F. Ethos

How would one attempt to legitimate or illegitimate the citation of foreign law using appeals to constitutional ethos? Bobbitt argues that ethical argument proceeds first by suggesting an implied limitation on the means by which the federal government may pursue legitimate ends, ends whose achievement are permissible official purposes. ${ }^{266}$

If the law or official action being challenged on ethical grounds is a state law or an action done by a state (as opposed to federal) actor, an additional step is necessary. Unlike the federal government, the states "are not creatures of limited, delegated purposes." ${ }^{267}$ The enumerated list of Article I, section 8 congressional powers ${ }^{268}$ is a list of the purposes with respect to which Congress may act to the policy domains in which Congress may act, not a list of tools by which Congress is empowered to achieve these ends. Chief Justice Marshall's famous line in McCullough v. Maryland (1819) is apt here: "Let the end be legitimate, let it be within the scope of the constitution, and all means which are appropriate, which are plainly adapted to that end, which are not prohibited, but consist with the letter and spirit of the constitution, are constitutional." ${ }^{269}$ Marshall is asserting that so long as Congress is empowered to achieve a certain type of result, it may use all of the means - all the policy tools - which fairly achieve that result, so long as those means are not themselves constitutionally forbidden.

Bobbitt says that when an action by a state is being challenged on ethical grounds, we say "as a general matter that those means denied [to] the federal government are also limitations of the states, by virtue of the integration of federal constitutional norms into the contours of state authority produced by the Civil War." ${ }^{270}$ States can do things that the

266. See BoвBit, supra note 5, at 150 ("What is needed . . is the same reasoning from the constitutional ethos that produced the Bill of Rights. The limited nature of federal governmental power suggests a means of generating that ethical perspective. First, a rule is suggested by the limited powers of the federal government.").

267. Id. (emphasis added).

268. U.S. CONST. art. I, §8.

269. McCulloch v. Maryland, 17 U.S. 316, 421 (1819).

270. BoBBITT, supra note 5, at 150 . As Bobbitt notes, it would be incorrect to say that this result was achieved via the vehicles of Reconstruction Amendments rather than via the war itself, $i d$. at 151 . The Civil War, Bobbitt says, was "a constitutional war," Id., 
federal government cannot do, but if the use of a particular means is forbidden to the federal government even in pursuit of an end that it may otherwise validly pursue, Bobbitt says, so is it forbidden to the states in pursuit of ends that they are otherwise constitutionally-entitled to pursue. ${ }^{271}$

Because ethical argument is so often directed against actions of the state and federal legislatures and executives, we may at first think that ethical argument simply has nothing to say about the propriety of citing foreign sources of law. But I think that this is incorrect. The outline of the ethical argument against the citation of foreign law is at least a little different from those of 'typical' ethical arguments, which tend to involve claims that the American people have impliedly withheld from a federal or state executive or legislative entity the power to use certain means for pursuing legitimate ends. In contrast, the ethical argument against citing foreign law is that the people have impliedly withheld from our judiciaries (certainly the federal judiciary and, via the transformation of the nature of state authority worked by the Civil War, state judiciaries as well) the means of citing foreign law even in pursuit of the end of resolving cases or controversies.

All power exercised by the government is derived from the American people. ${ }^{272}$ Obviously, this applies not only to the "legislative powers herein granted"273 and the "executive power," power"275 as well. Now, suppose one were to argue that it were highly improper for courts to cite foreign law because one believes, for whatever reason, that doing so just cuts deeply against the American ethos - that it just is not who we are to do this - if one believes this, then

these amendments, being "mere reflections of the constitutional change which generated them." Id.

271. See id. at 152 (" $[\mathrm{T}]$ he application of the ethic of limited constitutional government to the states yields the rule that states may not, in pursuit of their unenumerated and plenary ends, employ those means denied the federal government ... .").

272. See U.S. Const. pmbl. ("We the People of the United States . . . do ordain and establish this Constitution for the United States of America.") (emphasis added); $i d$. amend. IX ("The enumeration in the Constitution, of certain rights, shall not be construed to deny or disparage others retained by the people.") (emphasis added).

273. Id. art. I, § 1 .

274. Id. art. II, $\S 1$.

275. Id. art. III, $\S 1$. 
there is a plausible ethical claim that we have, in fact, impliedly deprived our judiciaries of ability to cite foreign law.

I would articulate the ethical objection to foreign law as follows: the American people may not be governed by laws over which they have no part in making. Such laws are foreign to our sensibilities and lack the democratic imprimatur we demand of the rules that bind us. Following Bobbitt's example, the ethical argument may be stated in this way: 1.) the judiciary is not explicitly empowered to impose foreign sensibilities on Americans; 2.) the citation of foreign law is not a necessary or proper means to carry out the legitimate judicial function of resolving cases and controversies; 3 .) the decision to adhere or not adhere to foreign cultural norms is reserved to the individual; 4.) the citation of foreign law outside of a context where the people have expressly or constructively approved of it amounts to the imposition of foreign sensibilities on them and eliminates, or at least diminishes, their ability to be governed exclusively by sensibilities of their own choosing.

Phrasing the ethical objection at this level of generality clarifies why most Americans wouldn't react with such hostility to a state court's citation of the law of sister-states. ${ }^{276}$ Such law may not be of 'our' making when 'we' are defined by reference to our states, but it is still 'ours' in some sense as Americans who share a common identity and legal heritage. It also clarifies why Americans wouldn't much object to a statute authorizing (or even requiring) courts to cite foreign law, nor to the use of foreign law in interpreting treaties. Neither of these examples involve the non-consensual imposition of foreign law on us-in both cases, we have in some way acquiesced to it.

To make sense of this argument, one would need to conceive of the citation of foreign law as a means to something, of which courts make usage in order to achieve the ends of deciding a case or controversy. Of course, the very means-ends distinction itself is "notoriously unreliable and [has] caused constitutional trouble in the past." 277 One may disagree

276. See Posner \& Sunstein, supra note 2, at 133 (" [I]t is quite standard to refer to the decisions of other jurisdictions .... [S] tate courts frequently refer to the judgments of other state courts in ruling on questions of private and public law, and indeed in ruling on the meaning of state constitutions.").

277. BobBitt, supra note 5, at 154. See, e.g., Carter v. Carter Coal Co., 298 U.S. 238,317 (1936) (striking down a tax on the grounds that it was used as a means to an impermissible end). The Court said: 
that this is the proper way to conceive of the citation of foreign law; one may say that citing foreign law isn't a matter of means or ends but of reasons; that it is about the reasons for which a court will employ the ordinary means of the judicial power, such as awarding damages, injunctions, and so on. Such means are totally with a court's power; the use of foreign law, one can say, is merely about the reasons a court will choose to use those means.

Damages and injunctions are absolutely some of the means by which court's exercise the judicial power-specifically, they are the means by which courts carry out their judgments. Enforcing judgments is a core component of the judicial power. But as a logical matter, judicial power must include the power to simply resolve cases or controversies in the first place. Courts have a power to reach judgments that is antecedent to its power to enforce judgments. The resolution of a case or controversy is an end in pursuit of whose achievement courts can be said to employ various means. Indeed, in Marbury v. Madison (1803), Chief Justice Marshall suggested that the very institution of judicial review is to be understood as merely a means by which a court achieves the end of deciding which litigant will prevail. ${ }^{278}$ In achieving the ends of deciding a case or controversy, courts employ various means. Many of these are things that are simply too obvious to even occur to us as 'means' at all, things like reading parties' briefs, conducting independent research, reading amicus briefs, reading treatises, and so on. There is at least a colorable claim that the use of foreign legal sources is a 'means' to a judicial end in this sense.

Id. at 291 .
Legislative congressional discretion begins with the choice of means and ends with the adoption of methods and details to carry the delegated powers into effect. The distinction between these two things - power and discretion - is not only very plain but very important. For while the powers are rigidly limited to the enumerations of the Constitution, the means which may be employed to carry the powers into effect are not restricted, save that they must be appropriate, plainly adapted to the end, and not prohibited by, but consistent with, the letter and spirit of the Constitution.

278. See Marbury v. Madison, 5 U.S. (1 Cranch.) 137, 177 (1803) ("It is emphatically the province and duty of the judicial department to say what the law is. Those who apply the rule to particular cases, must of necessity expound and interpret that rule. If two laws conflict with each other, the courts must decide on the operation of each."). 
The nonconsensual nature of the use of foreign law is key to the ethical objection. Many opponents of the citation of foreign law in other contexts nonetheless recognize the propriety of the practice with respect to the interpretation of treaties. ${ }^{279}$ Justice Scalia has said that "[w]e can, and should, look to decisions of other signatories when we interpret treaty provisions. Foreign constructions are evidence of the original shared understanding of the contracting parties. Moreover, it is reasonable to impute to the parties an intent that their respective courts strive to interpret the treaty consistently." ${ }^{280}$ In other words, treaties are like contracts between two or more sovereigns, and contracts should be construed to vindicate the intentions of contracting parties.

I would argue that the reason that treaties are different is because there is a consensual element to the use of foreign law to interpret treaties that is absent when foreign law is invoked in other contexts. When the American people, via their elected leaders, ratify a treaty, they do so subject to the understanding that foreign law may be used to interpret the treaty according to the intent of its signers. We can forbid, by statute, courts from doing this, or, even more crucially, we can just not ratify the treaty altogether. The consensual element that is present in this context makes the citation of foreign law less offensive to our constitutional ethos than it would otherwise be.

279. See, e.g., Sanchez, supra note 2, at 237 ("With the exception of cases that raise questions of international law because they involve treaty obligations or facts that otherwise implicate international law issues or non-American interests in some form, ... courts should make no such references" to foreign law.) (emphasis added); $c f$. Curtis J. Mahoney, Note, Treaties as Contracts: Textualism, Contract Theory, and the Interpretation of Treaties, 116 YALE L.J. 824 (2007) (proposing the use of a contract law framework for interpreting treaties).

280. Olympic Airways v. Husain, 540 U.S. 644, 660 (2004) (Scalia, J., dissenting). Scalia has elsewhere said:

I will use it in the interpretation of a treaty. In fact, in a recent case I dissented from the Court, including most of my brethren who like to use foreign law, because this treaty had been interpreted a certain way by several foreign courts of countries that were signatories, and that way was reasonable - although not necessarily the interpretation I would have taken as an original matter. But I thought that the object of a treaty being to come up with a text that is the same for all the countries, we should defer to the views of other signatories, much as we defer to the views of agencies - that is to say defer if it's within the ballpark, if it's a reasonable interpretation, though not necessarily the very best.

Dorsen, supra note 57, at 521. 
This is not the same as arguing that with respect to treatyinterpretation, Americans have waived their rights; as Bobbitt says, you can't invoke the notion of waiver in talking about ethical rights. ${ }^{281}$ Rather, this consent is what differentiates the invocation of foreign law for the purpose of interpreting treaties to its invocation for other purposes as a matter of our constitutional ethos. We can simultaneously have ethical objections to the nonconsensual imposition of foreign law on the American people in cases like Roper, ${ }^{282}$ but not object when it is used in a way to which we have implicitly or constructively agreed. Therefore, we can have impliedly withheld from our judiciaries only the power to engage in the former task, because they are different tasks.

But the \$64,000 question remains: are we the sort of people who find the notion of judges citing foreign law to be intolerable, such that we have impliedly denied our judiciaries the ability to do so? One could argue that the notion of self-determination and the imperative that we have a hand in the law that is to bind us are so central to the American ethos that it is unthinkable that we would willingly vest judges with the power to rely on foreign law in rendering decisions to the cases or controversies before them. Surely, this cannot be part of the "judicial power." 283 We are a people who rebelled against Britain and fought a war for our independence, who never joined any European Union-style leagues. One does get the sense that those who vigorously oppose the citation of foreign law often do so from what seems to be an ethical place. They really believe, on a fundamental level, that this practice is inconsistent with who we are as a people.

Consider the tenor of Gary Bauer's denunciation: "America is a unique nation, with a unique Constitution that has its own history," he says. ${ }^{284}$ "How can we interpret it based on the standards and values of judges in Zimbabwe?"285 Invoking the Americans who "spilled their blood ... to sever ties with England forever" during the Revolutionary

281. BoвBitт, supra note 5, at 146 ("If a right is that which is beyond governmental power, then government-induced waiver does not augment governmental power.").

282. Roper v. Simmons, 543 U.S. 551, 575-78 (2005).

283. U.S. CONST. art. III, § 1.

284. Gary Bauer, Disorder in our high court, U.S.A. TODAY, Mar. 21, 2005, at $23 \mathrm{~A}$.

285. Id. 
War, Congressman Ted Poe bemoans that "[n]ow, justices in this land of America . . . use British court decisions ... in interpreting our Constitution. What the British could not accomplish by force, our Supreme Court has surrendered to them voluntarily." 286 There is more than historical appeal going on here; there is a distinctly ethical cast to Bauer and Poe's statements, a sense that the citation of foreign law is not just unfaithful to the intentions or understanding of early Americans, but that it is in fact deeply un-American. Bauer and Poe really just don't feel, on a very fundamental level, that it is consistent with who 'we' are; their hostility is rooted in the American ethos.

In contrast to the structural argument against the citation of foreign law, there is something that may be labeled nationalistic or jingoistic about the ethical argument against foreign law, although I do not mean this in a pejorative sense. "The votes of foreign electorates are not events in our democracy," asserts Judge Richard Posner. ${ }^{287}$ "I think most Americans would think it outrageous that Zimbabwean judges, however distinguished they may be, were making law for us." 288 Justice Scalia insists that "we don't have the same moral and legal framework as the rest of the world, and never have." 289 Judges who believe in keeping the Constitution "up to date," he says, at least ought to "keep [it] up to date with the views of the American people. . . I'm sure that intelligent men and women abroad can make very intelligent arguments, but that's not the issue, because it should not be up to me to make those moral determinations." 290

But a 2006 article by Professor Calabresi makes the most studied and reasoned expression of this ethical sentiment. ${ }^{291}$ Americans, Professor Calabresi argues, are "an exceptional people and [have] an exceptional role to play in the world." ${ }^{292}$ Our uniqueness is an important part of our identity, he says: “Americans are more individualistic, more religious,

286. 151 ConG. ReC. H3105 (daily ed. May 10, 2005).

287. Posner, supra note 181.

288. Id.

289. Dorsen, supra note 57, at 521.

290. Id. at 533-34.

291. Steven G. Calabresi, "A Shining City on a Hill”: American Exceptionalism and the Supreme Court's Practice of Relying on Foreign Law, 86 B.U. L. REV. 1335 (2006).

292. Id. at 1337. 
more patriotic, more egalitarian, and more hostile to unions and Marxism than are the people of any other advanced democracy." ${ }^{293}$ Thus, he believes, hostility to foreign law is not just part of our history, but part of our character: "American popular culture overwhelmingly rejects the idea that the United States has a lot to learn from foreign legal systems, including even those of countries to which we are closely related like the United Kingdom and Canada." 294 Professor Calabresi's denunciation is rooted in a vision of the American ethos; he argues that citing foreign law runs contrary to the kind of people we are. "Most Americans think," he says, "that the United States is an exceptional country that differs sharply from the rest of the world and that must therefore have its own laws and Constitution." 295 It would be difficult to more thoroughly or cogently encapsulate the ethical objection to citing foreign law.

I suspect that the ethical objection to citing foreign law comes closest to reflecting the true psychological basis of opposition to the practice felt by many, if not most, of its foes. Bobbitt notes that judges sometimes gravitate to particular doctrinal arguments in cases where they may not be fully satisfying "because they are being pulled by the unacknowledged force of constitutional, ethical argument." 296 Sometimes when a court says one thing, "ethical arguments may actually be what is motivating the decision process." 297 Unsurprisingly, when other modalities "constructed as [] pretext[s]"298 to cloak ethical argument in action, this unconscious, unintended subterfuge can result in rather "unconvincing rationales." "299 In contrast, when foes of citing foreign law express their opposition in nakedly ethical terms, I believe they are being very candid about the true underlying bases for their conclusions. They are not using ethical appeal to cloak some other grounds for opposing the citation of foreign law; their disapproval is rooted in a genuine ethical intuition that invoking foreign law in non-consensual ways is inconsistent with the American character.

293. Id.

294. Id.

295. Id.

296. BoBвiтt, supra note 5, at 166-67.

297. Id. at 106.

298. Id. at 164 .

299. Id. at 167 . 
Perhaps the ethical legitimacy of citing foreign law is so difficult to assess because it is so subjective; either you truly believe that the practice is contrary to who we are as a people, to our American values and identity, or else you simply don't. One can, of course, easily deny that the American people do have such a deeply-felt objection to the citation of foreign law that we have impliedly withheld from our judiciaries the ability to invoke it where we have not given our express or constructive permission to do so. I would say, however, that within the ethical modality, there is at least a colorable argument that citing foreign law is illegitimate unless, as in the treaty-interpretation context, the American people have first given their (perhaps implied) consent.

\section{CONCLUSION}

So what, if anything, do we now know about the legitimacy of comparative constitutional law? Various arguments for and against the practice can be made, I believe, within each of the six modalities, though admittedly I find it easier to marshal arguments for it within certain modalities, like history and doctrine, and more difficult within others, like structure and ethos. Text and prudence, I believe, are fairly indeterminate; I find it more or less equally easy to make arguments both for and against the citation of foreign law within either modality. I would suggest that one who wants to argue for the propriety of citing foreign law will be able to mobilize arguments of various degrees of persuasiveness within any modality; one who argues against the practice can do the same.

On an individual level, whether a constitutional interpreter, lay or professional, concludes that citing foreign law is a legitimate practice in which judges may engage is a function of what sorts of arguments one personally finds persuasive or aesthetically appealing. These preferences, in turn, probably speak more about the interpreter than about any objective truth regarding the practice's propriety. With respect to this debate in particular, as with all constitutional debates, the existence of conflicts between and within the modal forms creates opportunity for decisions that are acts of conscience. The choice an interpreter makes when confronted with that opportunity doesn't say anything objectively true about the world, but only about the interpreter.

That said, I will make a few observations about the results of this survey, or at least, about how I understand them. It seems to me that 
textualism presents a fairly strong case for the citation of foreign law, but only for a particular usage of it. I perceive no strong textual argument for citing foreign law as controlling authority in a case. The opentexturedness of language seems to invite only the citation of foreign law in a persuasive manner, as one resource among many possible alternatives to which an interpreter may make recourse in order to construe an ambiguous or indefinite textual provision. Likewise, historicism provides a strong case for citing foreign law, but the early judicial decisions in which foreign law was used cited it likewise in what I would describe as more of a persuasive sense than a binding sense.

As for doctrinalism, despite what some critics fear, the usages of foreign law within the U.S. Reports seems mostly confined to the persuasive category - no recent Supreme Court decision of which I am aware has cited foreign law as binding authority on American courts. Meanwhile, the most fully-thought-out argument for citing foreign law as binding authority - the doctrinal need to bring American law into alignment with the law of other nations so that like cases will be treated alike worldwide - is also, in my mind, at least, the most obviously problematic; many would strongly deny, for reasons ranging from legal positivism to American sovereignty, that any such need actually exists. Prudential arguments for the citation of foreign law also seem to apply only to the use of foreign law as persuasive authority, furnishing reasoning that judges may choose to adopt or reject to the degree to which they find them compelling; the citation of foreign law as binding authority exacerbates the problem of judicial overreach.

In my mind, structuralism presents a powerful argument against the citation of foreign law, though once again, this argument has much weaker force with respect to the use of foreign law as persuasive rather than binding authority. Arguments against the citation of foreign law from ethos are so intertwined with and reflective of a deep moral intuition that reliance on foreign law, for at least some purposes, in incompatible with who we are as a people. But again, the force of this argument is greatly diminished when it is made with respect to citing foreign law as merely persuasive authority.

Having surveyed what these six modalities have to say about the legitimacy of citing foreign law, one may well conclude that as a general matter, it is constitutionally legitimate to cite foreign law for persuasive purposes, but not as binding authority. Of course, other conclusions can be reached as well, but this seems like the one that provides the best fit 
for full panoply of various modal arguments and counter-arguments that have been raised. At this point, it may be observed that almost nobody who defends the practice of using foreign law in American judicial decisions argues that it should be binding in any way on us; ${ }^{300}$ almost all merely suggest that it should be one source of persuasive authority among many, useful to the extent that it may provide judges with useful strands of reasoning, analogies, consequential illustrations, or other types of information. Given that this is so, the whole debate over citing foreign law seems overblown - perhaps we all actually disagree to a lesser extent than we think. 
